\title{
Large Infaunal Bivalves Determine Community Uptake of Macroalgal Detritus and Food Web Pathways
}

\author{
Agnes M. L. Karlson, ${ }^{1,2 *}$ Conrad A. Pilditch, ${ }^{3}$ P. Keith Probert,${ }^{2}$ \\ Daniel Leduc, ${ }^{4}$ and Candida Savage ${ }^{2,5}$
}

\begin{abstract}
${ }^{1}$ Department of Ecology, Environment and Plant Science, Stockholm University, Stockholm, Sweden; ${ }^{2}$ Department of Marine Science, University of Otago, Dunedin, New Zealand; ${ }^{3}$ School of Science, University of Waikato, Hamilton, New Zealand; ${ }^{4}$ National Institute of Water and Atmospheric Research (NIWA), Wellington, New Zealand; ${ }^{5}$ Department of Biological Sciences and Marine Research Institute (Ma-Re), University of Cape Town, Cape Town, South Africa
\end{abstract}

\begin{abstract}
Human activities alter biodiversity, influencing bottom-up and top-down control on food webs which can affect ecosystem functioning. In marine ecosystems, large bivalves play a critical role in benthic-pelagic coupling including nutrient cycling; however, their influence on the uptake of detrital organic matter by benthic communities is less understood. In a replicated factorial field experiment, we examined how the presence or absence (overharvesting scenario) of a large suspension-feeding clam on an intertidal sandflat and the addition of isotopically enriched macroalgal (Ulva sp.) detritus (eutrophication scenario) influenced infaunal biodiversity, and how changes in trophic interactions influenced key ecosystem functions (nutrient cycling and benthic metabolism and primary production). Both clams and Ulva increased community metabolism, but only clams had an effect on nutrient regeneration. We used the ${ }^{13} \mathrm{C}$ - and ${ }^{15} \mathrm{~N}$-enriched Ulva to quantify the ef-
\end{abstract}

Received 3 April 2020; accepted 10 June 2020;

published online 30 June 2020

Electronic supplementary material: The online version of this article (https://doi.org/10.1007/s10021-020-00524-5) contains supplementary material, which is available to authorized users.

Author Contributions: AMLK, CAP and CS conceived the study and analysed data. AMLK drafted the paper. All authors performed research and contributed to writing the paper.

*Corresponding author; e-mail: agnes.karlson@su.se fect of clams on detritus uptake in fauna and recovery in sediment. Due to their large biomass, nitrogen incorporation by clams constituted onethird of the infaunal community uptake after 14 days. Clam uptake likely resulted from ingestion of resuspended microphytobentos which had utilized ${ }^{15} \mathrm{~N}$ leaking out from decomposing Ulva. In plots without Ulva addition, the effect of clams on the overall resource utilization by the benthic community using natural abundance isotope niche metrics were tested. In plots without clams, the isotope niche of the community was reduced, and less carbon of pelagic origin was channelled into the infaunal food web. Our results imply that the loss of clams changes trophic pathways and reduces community uptake of macroalgal detritus, potentially exacerbating eutrophication. 


\section{Graphic Abstract}

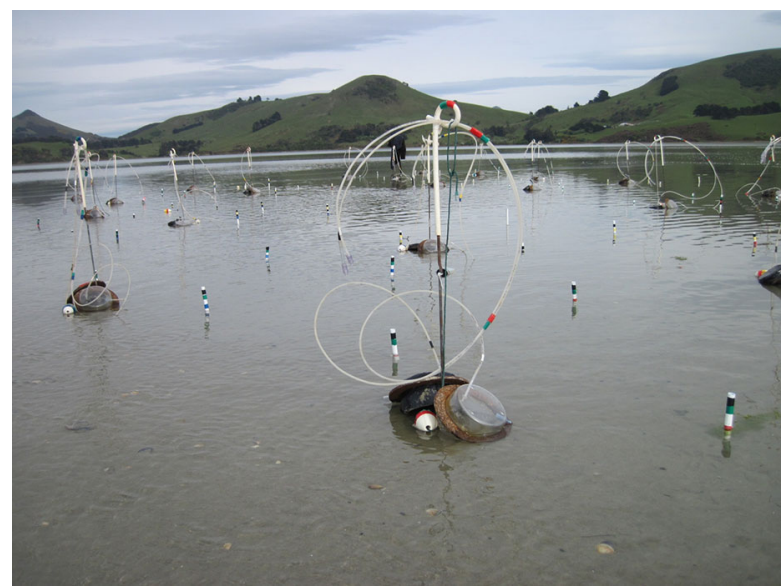

Key words: biodiversity-ecosystem function; benthic invertebrates; stable isotopes; keystone species; macroalgal blooms; nutrient cycling; estuary.

\section{Highlights}

- Field experiment testing top-down and bottomup effects on trophic ecosystem ecology.

- Clams counteract eutrophication by assimilating bloom-derived macroalgal nutrients.

- Reduced trophic niche of the benthic community in the absence of clams.

\section{INTRODUCTION}

Anthropogenic activities reduce biodiversity and alter species composition, influencing both bottomup and top-down control on food webs with potentially large effects on ecosystem functioning and ultimately the ecosystem services provided to humans (Duffy and others 2007; Cardinale and others 2012). Recent research on biodiversityecosystem functioning has revealed clear relationships between species richness, species identity or functional traits and ecosystem functions (for example, Cardinale and others 2012). Key challenges remain, however, in understanding how the environmental setting modulates relationships (for example, Hiddink and others 2009) and the underlying mechanisms (Karlson and others 2010, 2016). Such understanding is necessary for better predictions of how changing biodiversity will affect functioning to inform management strategies on a regional level.

Coastal soft sediments are global hotspots of biogeochemical cycling (Snelgrove and others 2014), and functionally important organisms such as large bivalves can disproportionally influence ecosystem functions such as nutrient cycling (Thrush and others 2006, 2014). Although the role of biodiversity and in particular large bivalves for cumulative processes (for example, nutrient fluxes which can be measured in situ in aquatic habitats) has been extensively studied (for example, Norkko and others 2013; Jones and others 2011), the direct and indirect effects of biodiversity on the fate of detritus (faunal uptake and subsequently trophic transfer) and associated changes in sediment biogeochemistry are poorly understood. Uptake of detritus is a fundamental ecosystem process where benthic infauna converts dead organic material to secondary production, which is then available for higher trophic levels (Snelgrove and others 1997).

Naturally occurring stable isotopes of carbon and nitrogen enable quantifiable measurement of resource use by all species in the community using isotope niche metrics (Newsome and others 2007; Layman and others 2007). Isotope spiking or labelling (Blair and others 1996; Herman and others 2000) is another approach that can be used to quantify individual uptake of a specific food source of interest, resolving trophic relationships and the outcomes of species interactions which amount to uptake at the community level. For example, species-poor communities are less efficient in the uptake of detritus compared to species-rich communities (Karlson and others 2010). However, loss of large bodied species can have a disproportionately large effect on ecosystem functions such as detrital uptake, potentially overriding the more subtle positive diversity effects arising from resource partitioning among species, and even negatively influencing the uptake rates of smaller species (Karlson and others 2016). Whether such large key species are positive for the overall community performance regarding resource utilization likely depends on the environmental conditions (for example, Rossi and other 2013). Using the two complementary isotope techniques (isotope niche analyses and labelled isotope uptake) and measurements of benthic solute fluxes in a field setting could be a useful approach to understand and 
predict the ecosystem response to stressors and species loss and to obtain a mechanistic understanding of trophic interactions underpinning ecosystem functioning under realistic environmental settings.

In New Zealand intertidal sandflat habitats, the large endemic venerid bivalve Austrovenus stutchburyi often occurs in dense beds where it dominates benthic biomass and is considered a key species. These suspension-feeding clams (locally referred to as cockles or littleneck clams) are important for benthic-pelagic coupling in estuaries and enrich organic matter content of sediment through their biodeposits (Norkko and others 2001). The species is a key organism that influences sediment characteristics and benthic community composition, which in turn affect ecosystem functions such as nutrient fluxes, oxygen dynamics and primary production (Thrush and others 2006; Sandwell and others 2009; Jones and others 2011). Clams are harvested for commercial and recreational purposes with concordant reductions in density and biomass in many estuaries (see Adkins and others 2014). An additional important stressor for many shallow coastal habitats, including New Zealand sandflats, is increased nutrient loading from land that results in excessive macroalgal blooms (Teichberg and others 2010; Marsden and Bressington 2009). In estuaries, macroalgae can provide nutrient subsidies to benthic ecosystems and be utilized for food by macrobenthos (for example, Rossi 2007; Karlson and others 2016); however, detritus from blooms may alter sediment biogeochemistry and, in turn, benthic communities and thus ecosystem functioning (Kelaher and Levinton 2003; Gladstone-Gallagher and others 2016). Several studies have investigated the effects of moderate macroalgal detritus subsidies (that is, increased organic matter availability that does not induce hypoxia) on benthic community composition and ecosystem functions related to nutrient regeneration in situ (for example, Kelaher and others 2013; GladstoneGallagher and others 2016) including the link to detrital uptake (Rossi and others 2013). We are not, however, aware of any field studies combining this low-level altered productivity base and key species manipulation with a mechanistic understanding of trophic relationships gained from a duel approach of isotopic labelling and isotope niche analyses. We address this knowledge gap by manipulating the presence or absence of a key bivalve at realistic densities and the presence and absence of isotopically enriched macroalgal detritus to surface sediments in an intertidal sandflat. By doing this, we can quantify simultaneously the effect of clams on both the overall resource use by the infaunal community (natural abundance isotope niche analyses) and trace the incorporation of enriched macroalgal detritus into infauna, thus closing the loop on shifts in trophic structure and ecosystem functions.

We predict that the removal of suspensionfeeding clams will result in a narrowing of the trophic niche of the community as assessed using the isotope niche of the most common benthic species. Increased competition for resources when clams are absent (that is, loss of biodeposits containing pelagic organic matter into the sediments) might, however, necessitate an increase in dietary niche breadth for remaining community members in order to maintain energy requirements (compare Svanbäck and Bolnick 2007). Empirical evidence indicates that interspecific competition can cause the niche widths of communities to increase or decrease depending on the environmental context (Karlson and others 2014). Regarding the Ulva manipulation, we anticipate that total uptake of added macroalgal detritus by the macrofaunal community will be lower in the absence of clams due to indirect effects; in laboratory experiments with intact communities, high clam density has been positively associated with higher Ulva uptake in a sub-surface deposit-feeding species (Karlson and others 2016) and in the field abundance of sub-surface feeders is positively associated with the presence of this clam (Thrush and others 2006). We expect that bioturbation by clams results in fresh detritus reaching sub-surface feeders and that they hence benefit from clam presence through increased food access. Further, we predict that decomposing detritus will lead to temporarily increased nutrient regeneration, resulting in increased primary production of microphytes at the sediment surface (compare Gladstone-Gallagher and others 2016). The effects of clam manipulation might be more complex since benthic primary productivity is positively influenced by clam excretion but negatively by physical disturbance and ingestion by clams (Thrush and others 2006; Sandwell and others 2009; Woodin and others 2016).

\section{MethodS}

\section{Study Site and Experimental Design}

A three-week manipulative field experiment was performed on an intertidal sandflat at Papanui Inlet on the Otago Peninsula, South Island of New Zealand (S 45.50.921, E 170.28.607) during the 
Southern Hemisphere spring (October-November) in 2012. Papanui Inlet is a sheltered inlet $\left(3.5 \mathrm{~km}^{2}\right)$ with minimal freshwater input and semidiurnal tides (Leduc and others 2009). Most of the inlet is exposed at low tide (mean tidal range of $1.15 \mathrm{~m}$ (Albrecht and Vennell 2007)) and consists of a patchwork of unvegetated sediments and seagrass beds (Zostera muelleri). The large suspension-feeding littleneck clam, Austrovenus stutchburyi occurs in high-density beds $\left(\sim 200-300\right.$ individuals $\left.\mathrm{m}^{-2}\right)$ in many areas of the intertidal sandflats (pers. obs.).

In a fully factorial design, we manipulated in situ $24 \mathrm{l} \mathrm{m}^{2}$ plots for the presence or absence of clams, A. stutchburyi, $\left(300\right.$ or $0 \mathrm{~m}^{-2}$ ) and macroalgal (Ulva) detritus ( 0 or $62 \mathrm{~g}$ dry weight $\mathrm{m}^{-2}$ ). To achieve interspersion of the treatments within a $100 \mathrm{~m}^{2}$ study area, we established six 'blocks' of four plots (in total 24 plots) and within each 'block' we randomly assigned one of four treatments: clams and no Ulva $(+\mathrm{C}-\mathrm{U}$, pristine), clams and Ulva $(+\mathrm{C}+\mathrm{U}$, altered productivity base), no clams no Ulva ( $-\mathrm{C}-$ $\mathrm{U}$, overharvested), and no clams with Ulva $(-\mathrm{C}+\mathrm{U}$, overharvested and altered productivity base) (Supplementary Figure S1). There was approximately a $1-2 \mathrm{~m}^{2}$ buffer zone between treatment plots and 'blocks'. We did not consider a 'block' effect in statistical tests (see below) because there was no obvious environmental gradient in the small study area and the inter-plot and inter-block distances were comparable so that the plots (and accompanying buffer zones) occupied the entire site (Hewitt and others 2007).

\section{Bivalve Density Manipulation}

Clam density in the 24 experimental plots was manipulated on 15-16 October 2012 at low tide by finger ploughing the plots and buffer zone to remove clams (Figure 1, d -7). On average, excavated plots contained about 100 clams, weighing about $1.2 \mathrm{~kg}$ wet weight (ww). We returned 300 clams, about $4.1 \mathrm{~kg} \mathrm{ww}$, to all $+\mathrm{C}$ plots (12 plots) and buried them in the upper $1-2 \mathrm{~cm}$ in the sand preserving their natural orientation. This density and biomass of clams although higher than the study site are consistent with averages for other parts of Papanui Inlet and similar estuaries in Otago and Southland (C Savage unpubl. data). Plots were inspected the day after the manipulation; no mortality was recorded; and clams were feeding at high
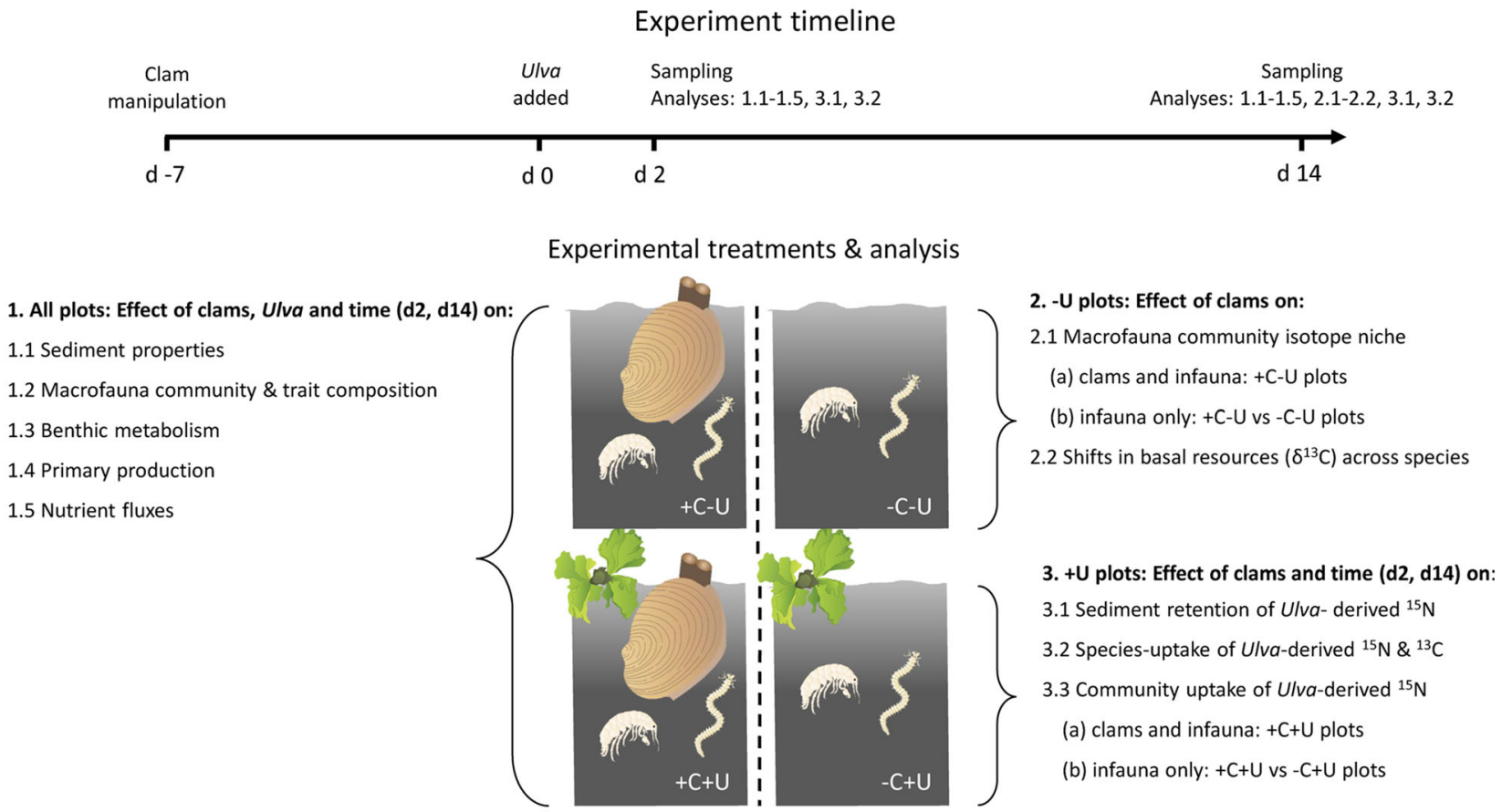

Figure 1. Schematic of the experimental design and the ecosystem functions measured. Each treatment had 6 replicates $\left(1 \mathrm{~m}^{2}\right.$ plots), and the treatments were evenly dispersed in the experimental area of $100 \mathrm{~m}^{2}$ (see text for details). In each plot, paired light and dark benthic chambers were used to measure exchange of oxygen and nutrients across the sedimentwater interface and faunal composition on two sampling occasions ( $\mathrm{d} 2$ and $\mathrm{d} 14$ ). Macrofauna were analysed for isotope composition: natural abundance data and subsequence niche metrics were calculated in the $-\mathrm{U}$ plots on dl4, and in the $+\mathrm{U}$ plots enriched isotope data originating from detritus were calculated to faunal uptake and sediment recovery on $\mathrm{d} 2$ and d 14 . 
tide. At low tide, faecal casts from the maldanid polychaete Macroclymenella stewartensis, ejected sediment mounds of the burrowing shrimp Biffarius filholi, and burrowing holes from the mantis shrimp Heterosquila tricarinata, were recorded at the site indicating normal faunal activity after the manipulation

\section{Isotope Labelling and Addition of Ulva}

Prior to the start of the experiment, Ulva spp. thalli were collected from Papanui Inlet during June to September (2012) and incubated with filtered seawater enriched with stable carbon and nitrogen isotopes (bicarbonate, 99\% purity, and ammonium sulphate, $10 \%$ purity, Cambridge isotopes, 0.3 and $1 \mathrm{~g}$ per $10 \mathrm{~L}$, respectively) for about one week at $16^{\circ} \mathrm{C}$ with constant light in the laboratory. After each incubation, the Ulva thalli were rinsed in freshwater to remove non-assimilated isotopes and freeze-dried. A total of $750 \mathrm{~g} \mathrm{dw}$ isotopically labelled Ulva was obtained (corresponding to about $6 \mathrm{~kg}$ wet weight). All the labelled Ulva material was fragmented into small pieces $\left(\sim 5 \mathrm{~mm}^{2}\right)$ and homogenized to avoid inter-batch differences in isotope enrichment. The final pooled sample of Ulva detritus was $\delta^{15} \mathrm{~N}=5462 \pm 65 \%$ and $\delta^{13} \mathrm{C}=$ $239 \pm 4 \%$.

We added $62 \mathrm{~g}$ dry weight (dw) of isotope-enriched Ulva to the twelve $+\mathrm{U}$ plots 6 days after the clam manipulation at low tide on 21 October (Figure 1, d 0). The quantity added was based on a pilot study that determined the addition that did not cause hypoxia of the surface sediment but instead reflected low-level eutrophication-induced increases in macroalgal abundance. Although the amount added was rather low compared to previous in situ studies using macroalgal detritus (Rossi and others 2013; Gladstone-Gallagher and others 2016), for Papanui Inlet, which has a very low sediment $\mathrm{N}$ content, the addition was significant, corresponding to an increase of $25 \% \mathrm{~N}$ in the top $2 \mathrm{~cm}$ sediment layer. The Ulva flakes were gently massaged into the upper $1-2 \mathrm{~cm}$ of the sediment with the other twelve $-\mathrm{U}$ plots disturbed in the same way (without adding Ulva).

\section{Field Sampling and Analyses}

\section{Nutrient and Oxygen Flux Measurements}

We measured fluxes of oxygen and nutrients across the sediment-water interface in situ on two occasions: 2 and $14 \mathrm{~d}$ after addition of the Ulva (hereafter $\mathrm{d} 2$ and d14, Figure 1) to quantify initial and delayed responses in ecosystem functions (Glad-
stone-Gallagher and others 2016). Solute fluxes were measured using paired light and dark benthic chambers (area $0.016 \mathrm{~m}^{2}$, volume $0.85 \mathrm{~L}$; cover image) in each of the 24 plots following the methods of Lohrer and others (2010). Care was taken to place chambers on the shore side of each plot on $\mathrm{d} 2$ and on the seaside of the plots on d 14 to minimize disturbance from the first sampling for the second sampling. Chambers were gently pushed into the upper $1 \mathrm{~cm}$ of the sediment, taking care to minimally disturb the sediment. Tubing was connected to the chambers to enable sampling during tidal immersion (tube length $\sim 180 \mathrm{~cm}$ ). In addition, we collected a sample of ambient bottom water from six locations scattered across the study site each time the chambers were sampled. At the same locations, we incubated site water in paired light and dark bottles (concurrent with chamber deployments) to account for water column processes in measurements of benthic chamber solute fluxes.

Fluxes of oxygen and nutrients (ammonium; $\left.\mathrm{NH}_{4}{ }^{+}\right)$, nitrate and nitrite $\left(\mathrm{NO}_{x}\left(=\mathrm{NO}_{3}+\mathrm{NO}_{2}\right)\right)$ and dissolved reactive phosphorous (DRP) were quantified by measuring changes in solute concentrations during chamber incubation. Flux calculations were based on initial and final chamber water samples corrected for water column processes (which accounted for $<8 \%$ of the measured benthic flux) (Lohrer and others 2010). An initial water sample was taken at the start of the incubation and $3.5 \mathrm{~h}$ later. The water samples were directly taken to shore and oxygen concentration measured using a PreSens FIBOX 3 optical sensor. Thereafter, the water was filtered through a GFF $(0.45 \mu \mathrm{m})$ filter and stored on ice and later frozen for nutrient analyses. The same procedure was repeated with the final water samples. The frozen water samples were thawed in the laboratory, and dissolved inorganic nutrient analysis was performed using standard methods for seawater on an Astoria-Pacific 300 series segmented flow autoanalyser (detection limit of $1 \mu \mathrm{g} \mathrm{L}^{-1}$ for $\mathrm{N}$ and $\mathrm{P}$ ).

Fluxes measured in the incubation chambers were used to evaluate key processes indicating ecosystem functions (Figure 1, 1.3-1.5). Dissolved oxygen (DO) fluxes were used to estimate net primary production (NPP; light chamber DO flux), community metabolism (sediment oxygen consumption (SOC); dark chamber DO flux), as well as gross primary production (GPP; calculated from the difference between light and dark DO fluxes, that is, NPP + SOC). Estimates of gross nutrient regeneration (that is, without uptake by photosynthe- 
sizing microphytobenthos) were derived from the dark chamber $\mathrm{NH}_{4}{ }^{+}, \mathrm{NO}_{\mathrm{x}}$ and DRP fluxes.

\section{Benthic Fauna and Sediment Sampling Analyses}

At low tide following incubations, macrofauna core samples $($ dia $=13 \mathrm{~cm})$ were taken within each chamber to $15 \mathrm{~cm}$ depth, sieved $(0.5 \mathrm{~mm})$ within $24 \mathrm{~h}$ and preserved in 70\% ethanol (Figure 1, 1.2). Macrofauna were stained in Rose Bengal, identified and counted under stereomicroscope to the lowest possible taxonomic level (usually species level, see Table 2 and Suppl. Table 1). Individual shell-free dry weight $\left(60^{\circ} \mathrm{C}\right.$ until constant weight) was measured for intact individuals of the species listed in Table 1 (details under isotope analyses). On d2, macrofauna core holes were filled with clean azoic sand to avoid disturbance in the rest of the plot from collapsed sediment. Surface sediment $(0-$ $2 \mathrm{~cm}$ ) samples were collected on both $\mathrm{d} 2$ and $\mathrm{d} 14$ for sediment properties and chlorophyll $a$ concentration (as a proxy for microphytobenthos biomass) using syringe cores (dia $2 \mathrm{~cm}, n=3$ from each plot and pooled for analysis). Sediment samples using the same method were also collected for recovery measurements of Ulva fragments (visual observations of algal fragment presence and size as well as isotope analyses as described in, one syringe core per plot, Figure 1, 3.1). These sediment samples were stored on ice and later frozen. In addition, surface sediment (top $2 \mathrm{~cm}$ ) was sampled from each plot on dl4 for nematode stable isotope analyses, as described in Leduc and others (2009).

Chlorophyll $a$ (Chl-a) and phaeophytin concentrations, organic content and grain size of sediment (Figure 1, 1.1) were analysed as in Pratt and others (2015). Briefly, pigment samples were freeze-dried and homogenized. A small quantity of sediment $(\sim 0.1 \mathrm{~g})$ was soaked in $10 \mathrm{ml}$ of $\mathrm{MgCO}_{3}$ buffered acetone $(90 \%)$ for approximately $20 \mathrm{~h}$. Samples were shaken and again after $12 \mathrm{~h}$ prior to centrifugation for $10 \mathrm{~min}$ at $3300 \mathrm{rpm}$ before fluorometric analysis. Sediments for particle size analysis were digested in $10 \%$ hydrogen peroxide, to remove organic matter until bubbling ceased before using the standard operating procedure for marine sediments on a Malvern Mastersizer-S (300 FR lens) to determine grain size fractions in the range of $0.05-2000 \mu \mathrm{m}$. Organic content was estimated from weight loss on ignition $\left(4 \mathrm{~h} 450^{\circ} \mathrm{C}\right)$ on sediment samples that had been dried for $24 \mathrm{~h}$ at $60^{\circ} \mathrm{C}$.

\section{Isotope Analyses of Sediment and Benthic Fauna}

Sediments were subsampled and analysed for stable isotope ratios from the homogenized upper
$2 \mathrm{~cm}$ layer from each plot from both $\mathrm{d} 2$ and $\mathrm{d} 14$ (Figure 1, 3.1). Nematodes and the ten most abundant macrofaunal species or species of the largest biomass (Table 1) from the surface sediment and the benthic chambers, respectively (see above), were analysed for natural abundance isotopes and isotope enrichment on d 14 (Table 1 , Figure 1, 2.1-2.2, 3.2-3.3). The three species with highest enrichment on dl4 were also analysed on d2. Ethanol preservation effects on isotope composition are considered small (Lau and others 2012) and because all samples were treated the same can be disregarded in this study. In total, 177 macrofaunal individuals were analysed for isotope enrichment (among the $12+\mathrm{U}$ plots) and 46 individuals analysed for natural abundance isotope analyses (from the $12-\mathrm{U}$ plots). Within species (and days), similar sized, adult individuals were selected to minimize biomass/growth dependent enrichment (Karlson and others 2016). This was challenging for Nereididae (polychaetes) which were generally present as one small specimen/juvenile per core but occasionally as a large individual and so were excluded from one statistical test on natural isotope abundance (described below). For species with large biomass (only the polychaete $M$. stewartensis and the clam A. stutchburyi; Table 1), a pooled homogenized sample from one core per plot (median no. of individuals per core $=6$ for both species) was used to get a representative sample for analyses. For abundant species with a small biomass (amphipods), the first 2-10 individuals (depending on species individual biomass) encountered from each core were collected and transferred to a pre-weighed tin capsule to obtain sufficient biomass (about $2 \mathrm{mg} \mathrm{dw}$ ) for analyses. Nematode samples consisted of up to several hundred pooled individuals which amounted to a dry weight of about $10-80 \mu \mathrm{g}$. In the statistical analyses, the plot was used as the level of replication (hence for those species originating from the duplicate cores within one plot were averaged to get one value per plot). Generally $n=6$ for each species and treatment, however, $n$ varies among statistical analyses on individual level (for example, isotope composition comparison among species) as some species were not present in every plot.

Species/taxa selected for isotope analyses were dried at $60^{\circ} \mathrm{C}$ and packed in tin capsules as described above; sediment was analysed in aliquots of $20 \mathrm{mg} \mathrm{dw}$ (because of the low $\mathrm{N}$ content). Isotope analyses were conducted at IsoTrace (University of Otago, Dunedin, New Zealand) on 
Table 1. The Macrofaunal Species Analysed for Stable Isotopes Listed by Their \% Contribution to Community Biomass (Based on Abundance and Individual Shell-Free Dry Weight)

\begin{tabular}{|c|c|c|c|c|c|c|c|c|}
\hline Species & $\begin{array}{l}\text { Taxonomic } \\
\text { group }\end{array}$ & $\begin{array}{l}\text { Feeding } \\
\text { group }\end{array}$ & $\begin{array}{l}+\mathrm{C}+\mathrm{U} \\
\text { ind } \mathrm{m}^{-2}\end{array}$ & $\begin{array}{l}+\mathrm{C}-\mathrm{U} \\
\text { ind } \mathrm{m}^{-2}\end{array}$ & $\begin{array}{l}-\mathrm{C}+\mathrm{U} \\
\text { ind } \mathrm{m}^{-2}\end{array}$ & $\begin{array}{l}-\mathrm{C}-\mathrm{U} \\
\text { ind } \mathrm{m}^{-2}\end{array}$ & $\begin{array}{l}\text { Mean } \\
\text { biomass } \\
\left(\text { mgind }^{-1}\right)\end{array}$ & $\begin{array}{l}\text { \% Contrib. } \\
\text { shell-free } \\
\text { biomass }\end{array}$ \\
\hline $\begin{array}{l}\text { Austrovenus stutch- } \\
\text { buryi }\end{array}$ & Venerid bivalve & susp & 452 & 452 & 0 & 0 & 400 & $\mathrm{Na}$ \\
\hline $\begin{array}{l}\text { Macroclymenella } \\
\text { stewartensis (4) }\end{array}$ & $\begin{array}{l}\text { Maldanid poly- } \\
\text { chaete }\end{array}$ & $\begin{array}{l}\text { head-down } \\
\text { dep }\end{array}$ & 358 & 396 & 433 & 377 & 8.242 & $62 \%$ \\
\hline $\begin{array}{l}\text { Torridoharpinia } \\
\text { hurleyi (2) }\end{array}$ & Amphipod & $\begin{array}{l}\text { 50:50 pred/ } \\
\text { scav }\end{array}$ & 1093 & 1112 & 1225 & 1696 & 0.565 & $14 \%$ \\
\hline $\begin{array}{l}\text { Waitangi brevi- } \\
\text { rostris (3) }\end{array}$ & Amphipod & $\begin{array}{l}\text { 50:25:25 } \\
\quad \text { dep/ } \\
\text { scav/graz }\end{array}$ & 641 & 415 & 584 & 660 & 0.683 & $7 \%$ \\
\hline $\begin{array}{l}\text { Paracorophium } \\
\text { excavatum (1) }\end{array}$ & Amphipod & susp & 1338 & 1093 & 1998 & 1281 & 0.174 & $5 \%$ \\
\hline $\begin{array}{c}\text { Edwardsia neoze- } \\
\quad \text { landica (9) }\end{array}$ & Anthozoan & $\begin{array}{l}\text { 50:50 pred/ } \\
\text { scav }\end{array}$ & 94 & 75 & 94 & 151 & 2.108 & $4 \%$ \\
\hline Nereididae (13) & $\begin{array}{l}\text { Nereidid poly- } \\
\text { chaete }\end{array}$ & $\begin{array}{l}\text { 50:50 pred/ } \\
\text { scav }\end{array}$ & 75 & 75 & 75 & 38 & $\begin{array}{l}3.108 \\
\quad(0.8-35)\end{array}$ & $4 \%$ \\
\hline $\begin{array}{l}\text { Zeuxo novaezealan- } \\
\text { diae (6) }\end{array}$ & Tanaidacean & dep & 226 & 283 & 283 & 170 & 0.249 & $1 \%$ \\
\hline $\begin{array}{l}\text { Prionospio auck- } \\
\text { landia (14) }\end{array}$ & $\begin{array}{l}\text { Spionid poly- } \\
\text { chaete }\end{array}$ & dep & 57 & 75 & 57 & 75 & 0.861 & $1 \%$ \\
\hline Anthuridae (15) & Isopod & $\begin{array}{l}\text { 50:50 pred/ } \\
\text { scav }\end{array}$ & 113 & 38 & 38 & 75 & 0.36 & $0.5 \%$ \\
\hline $\begin{array}{l}\text { Paracalliope } \\
\text { novizealandiae } \\
\text { (5) }\end{array}$ & amphipod & $\begin{array}{l}\text { 50:25:25 } \\
\quad \text { dep/ } \\
\text { scav/graz }\end{array}$ & 283 & 245 & 302 & 622 & 0.04 & $0.3 \%$ \\
\hline
\end{tabular}

The mean community biomass (excluding clams $\left(90 \mathrm{~g} \mathrm{~m}^{-2}\right)$ ) was $5 \mathrm{~g} \mathrm{~m}^{-2}$. For simplicity the combined median value for $d 2$ and $d 14$ is presented and the ranking based on abundance of each species is presented in parentheses. Taxa ranked 7 (Cumacea), 8 (Oligochaetea), 10 (Paraonidae), 11 (Syllidae) and 12 (Arthritica bifurca) were either too small in individual biomass $(7,8,12)$ or the specimen encountered during sorting too fragile/broken to be used in isotope analyses. The most abundant species, a bivalve $<1 \mathrm{~mm}$ long, Legrandina turneri (c. 18000 ind $\mathrm{m}^{-2}$ ) was not included since its contribution to community biomass was negligible (< $\left.0.1 \%\right)$. Nematodes constitute about $2 \%$ of community biomass. Feeding group (after Greenfield and others 2016) abbreviations: susp suspension feeder, dep deposit feeder, pred predator, scav scavenger, graz grazer. See Table S1 for complete species list.

a Europa 20-20 Hydra stable isotope mass spectrometer (Europa Scientific) interfaced to a Carlo Erba Analyzer (NA1500) in continuous-flow mode (precision $0.2 \%$ ). Analysis was calibrated to EDTA laboratory standard reference materials (Elemental Microanalysis) and standardized against international standards (IAEACH-6 for carbon, IAEAN1 and IAEAN2 for nitrogen). Results are expressed relative to standards (Vienna $\mathrm{PDB}$ for carbon and atmospheric $\mathrm{N}$ for nitrogen) in standard delta notation according to the formula:

$$
\delta^{13} \mathrm{C} \text { or } \delta^{15} \mathrm{~N}=\left[\left(R_{\text {SAMPLE }} / R_{\text {STANDARD }}\right)-1\right] \times 10^{3 \%} \%
$$

where $R$ is the ratio of ${ }^{13} \mathrm{C} /{ }^{12} \mathrm{C}$ or ${ }^{15} \mathrm{~N} /{ }^{14} \mathrm{~N}$.

\section{Data and Statistical Analyses}

Treatment Effects on Sediment Properties, Macrofaunal Species Composition and Ecosystem Functions

Although not our main focus, we expect the experimental manipulations (clam density manipulation and detritus addition) to affect the community composition of infauna through reductions in clam-associated fauna (compare Cesar and Frid 2009) and increases in mobile opportunistic epifauna attracted to the detritus (Figure 1, 1.2). Furthermore, we predict that decomposing detritus will lead to temporarily increased nutrient regeneration and consequently increased primary production (Figure 1, 1.4-1.5) from microphytes in the sediment surface (compare Gladstone-Gallagher and others 2016). The presence of clams as 
well as addition of detritus was expected to influence benthic metabolism (Figure 1, 1.3). Permutational analysis of variance, PERMANOVA (PERMANOVA + in PRIMER v6; Anderson and others 2008), was used to compare sediment properties, macrofauna community composition (excluding clams which were manipulated) and total abundance of key-species and functional feeding groups as well as solute fluxes between treatments and time (Figure 1, 1.1-1.5). The analysis consisted of a three-way repeated measures design with plots nested as a random factor within the manipulated treatments $(n=6$ plots per treatment). The three fixed factors were: (1) clam manipulation ( $\mathrm{C}$; 2 levels: $+\mathrm{C},-\mathrm{C})$, (2) Ulva detritus addition (U; 2 levels: $+\mathrm{U},-\mathrm{U}$ ) and Time (sampling day; 2 levels; $\mathrm{d} 2$ and $\mathrm{d} 14$ ).

The species abundance for each plot/sample day was the average of the two cores taken under the light and the dark chambers. Species composition data were square root-transformed prior to creating the resemblance matrix generated from betweensample similarities (Bray-Curtis dissimilarity). Multivariate data were visualized for treatment and sampling day effects in multidimensional scaling (MDS) plots. To obtain a more mechanistic understanding for potential changes in species composition related to the altered resource base expected from clam and Ulva manipulations, the macrofaunal species were included in a biological traits matrix containing five feeding behaviours (suspension-feeding, deposit-feeding, grazers, predators and scavengers according to fuzzy coding (0-1) (Greenfield and others 2016). The abundance of each species was multiplied by the presence of each trait and the total abundance of this trait within a core was achieved by summing all species values. An individual test was carried out for each of the five feeding traits using the three-way repeated measures design described above (based on Bray-Curtis dissimilarity).

Sediment properties (grain size, organic content (loss on ignition) and pigment concentration (Chl$a$, phaeophytin)) were normalized and then combined in a resemblance matrix. GPP, NPP, SOC and nutrient fluxes $\left(\mathrm{NH}_{4}, \mathrm{NO}_{x}\right.$ and DRP) were tested individually. The analyses, based on the same three- way repeated measures design described above, were run using Euclidean distance and all analyses with 9999 permutations of residuals under a reduced model (Figure 1, 1.1). We adopted an $\alpha$ level of 0.05 , where we obtained $p$ values between 0.05 and 0.06 results were reported as marginally significant.
Community-Wide Measures of Resource Use from Natural Abundance Isotope Niche Analyses

To test the hypothesis that clams directly as well as indirectly affect community trophic niche breadth, isotope niche metrics (Layman and others 2007) were calculated for the treatments without the isotope-enriched Ulva addition $(+\mathrm{C}-$ $\mathrm{U}$ and $-\mathrm{C}-\mathrm{U}$, Figure 1, 2.1) using the SIBER (Stable Isotope Bayesian Ellipses in R); Jackson and others 2011) package for R v3.6.1. The indirect effect was tested by comparing infauna between the $+\mathrm{C}-\mathrm{U}$ and $-\mathrm{C}-\mathrm{U}$ treatments (Figure $\mathrm{l}$, $2.1 \mathrm{~b})$, whereas the direct effect included clams in the comparison (Figure 1, 2.1a). The convex hull area is the total area encompassed by all species; the other Layman metrics represent different aspects of trophic diversity. A large $\delta^{15} \mathrm{~N}$ range $(\mathrm{dN})$ indicates greater trophic diversity in terms of the trophic position and potential for omnivory, whereas a large $\delta^{13} \mathrm{C}$ range $(\mathrm{dC})$ indicates multiple carbon resources (for example, benthic, pelagic, terrestrial subsidies) and potential for niche diversification. Mean nearest neighbour distance (MNND) describes how individuals are distributed relative to one another within the dietary niche space of the population or the community, with higher values indicating greater dietary divergence. The standard ellipse area, SEA, (Jackson and others 2011) provides information on the core aspects of the isotope niche (comparable to SD in univariate cases), excluding species identity (species identity included in convex hull calculations) but enabling statistical comparison with Bayesian inference $\left(\mathrm{SEA}_{\mathrm{B}}\right)$ and overlap calculations between treatments. Finally, as a complement to niche analyses, absolute shifts in $\delta^{13} \mathrm{C}$ can be used to trace pelagic utilization in infauna; this was hypothesized to be more pronounced when clams were present since deposit feeders would feed on clam biodeposits (Figure 1, 2.2). The effect of clam removal on the mean $\delta^{13} \mathrm{C}$ value in infauna was tested using a paired $t$ test since sample size within species for natural abundance was rather low and variable. Out of the ten infauna analysed for stable isotopes, Nereididae, which had a highly variable body mass, and the tanaidacean Zeuxo novaezealandiae, which likely migrated between $\mathrm{U}$ and $+\mathrm{U}$ plots based on highly variable isotope values (see Results), were excluded from this analysis. 

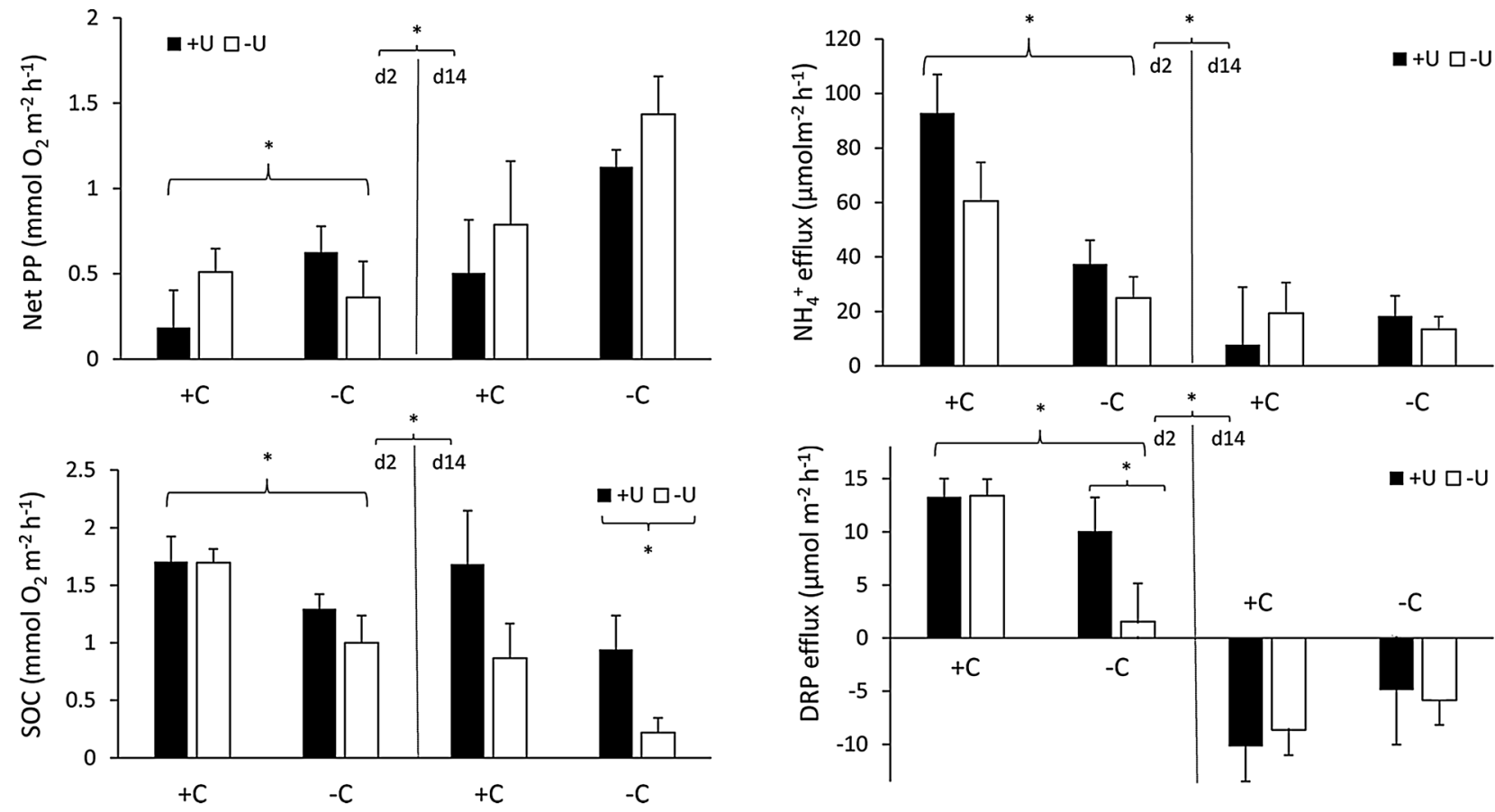

Figure 2. Sediment oxygen consumption (SOC), net primary production (net PP) and ammonium $\left(\mathrm{NH}_{4}{ }^{+}\right.$) and phosphate (DRP) efflux from the sediment as a function of sampling day (d2 on left and d 14 on right), and presence or absence of clams $(+\mathrm{C},-\mathrm{C})$ and Ulva detritus (+U: black bars; $-\mathrm{U}$ : white bars). Values are the mean $+\mathrm{SE}, n=6$. PERMANOVA main effects or pair-wise test (nutrients only) results for significant effects are depicted by asterisks PERMANOVA (see Table 2 for full results). Asterisk for $+\mathrm{U}$ effect for DRP flux refers to a follow-up Mann-Whitney $\mathrm{U}$ test $(Z=2.00, p=0.04)$.

Fate of Enriched Ulva-Derived Nitrogen and Clam Removal Effects on Uptake

All taxa feeding on the added detritus in Ulva treatments were expected to have higher values of both $\delta^{15} \mathrm{~N}$ and $\delta^{13} \mathrm{C}$ compared to their conspecifics in the no Ulva treatments. For those species where isotope enrichment was not obviously higher than natural abundance levels (four of the 11 species tested, see Results), differences in $\delta^{15} \mathrm{~N}$ and $\delta^{13} \mathrm{C}$ between $+\mathrm{U}$ and $-\mathrm{U}$ plots were tested separately for each isotope and species using PERMANOVA with Ulva as fixed effect (unrestricted permutations since only one factor was tested).

For the three species which were also analysed on d2 (only those with high enrichment on d14, see Methods), isotope enrichment was expected to be lower due to the shorter time for feeding and assimilation of the isotope-enriched detritus. In contrast, enrichment in sediment was expected to decrease over time due to loss from resuspension, degradation and faunal feeding. To test the effect of Clam removal and Time on $\delta^{15} \mathrm{~N}$ in sediment in the $+\mathrm{U}$ plots, a repeated measures PERMANOVA design was used (Figure 1, 3.1). To test the hypothesized positive effect of clams through enhanced burial of detritus on ${ }^{15} \mathrm{~N}$ and ${ }^{13} \mathrm{C}$ enrichment in sub-surface feeders (only one species of this feeding group was abundant; $M$. stewartensis), a repeated measures design was used in the $+U$ plots with Time and Clam as fixed factors (Figure 1, 3.2). The other two taxa (Nereididae and Z. novaezealandiae) which were sampled on both $\mathrm{d} 2$ and $\mathrm{d} 14$ were not found in every plot so the repeated measures analysis could not be used. For these two taxa, and all other taxa except $A$. stutchburyi, clam removal effects on $\delta^{15} \mathrm{~N}$ and $\delta^{13} \mathrm{C}$ values in $+\mathrm{U}$ plots were tested for each taxa separately (on d14) using PERMANOVA (unrestricted permutations), since potential responses are likely related to the speciesspecific feeding mode. One individual each of $P$. aucklandica and Nereididae were considered obvious outliers and removed prior to isotope enrichment statistical analyses.

To quantify the uptake of Ulva-derived nitrogen, more specifically the label incorporation (LI, expressed as $\mu \mathrm{g}{ }^{15} \mathrm{~N}$ ) by fauna, the product of excess ${ }^{15} \mathrm{~N}$ (E) and biomass of nitrogen in each species, was calculated (Herman and others 2000). Excess ${ }^{15} \mathrm{~N}$ is the difference between the fraction ${ }^{15} \mathrm{~N}(\mathrm{~F})$ of sample and control (non-enriched specimen), that is, 


$$
E=F_{\text {sample }}-F_{\text {control }}
$$

where $\mathrm{F}=\mathrm{R} / \mathrm{R}+1$ and where $\mathrm{R}$ can be calculated from the measured $\delta^{15} \mathrm{~N}$ using the $\mathrm{R}_{\text {standard }}$ of 0.003677 (see equation 1 ). This amount was multiplied by the number of individuals of the respective species core ${ }^{-1}$ then scaled to $\mathrm{m}^{-2}$. (For nematodes, density estimates were taken from Leduc and others 2009.) To obtain community uptake of Ulva-N (Figure 1, 3.3), the species-specific total LI (uptake) (based on core-specific density) were summed. Sediment retention of Ulva-derived $\mathrm{N}$ was calculated using the same approach and $\mathrm{N} \%$ of 0.1 and a dry density of $2.3 \mathrm{~g} \mathrm{~cm}^{-3}$. Uptake of Ulvaderived carbon was not calculated since the enrichment was not significant for several species (see Results) and labelled $\delta^{15} \mathrm{~N}$ and $\delta^{13} \mathrm{C}$ were positively correlated for all species except $A$. stutchburyi (Table S3).

The total uptake of Ulva-N in the macrofaunal community was compared between the $+\mathrm{C}+\mathrm{U}$ and $-\mathrm{C}+\mathrm{U}$ treatments using PERMANOVA, based on Euclidean distance (log-transformed). To test whether clam removal could be partially compensated for by other infaunal community members (a combined effect of potentially different uptake rates and/or altered abundance of other infauna in clam removal plots), community uptake of Ulva-N was tested between $+\mathrm{C}+\mathrm{U}$ (excluding clams) and $-\mathrm{C}+\mathrm{U}$ treatments using a PERMANOVA (Figure 1, 3.3b).

\section{RESUltS}

Effects of Clam Manipulation, Ulva Addition and Time on Species Composition and Sediment Characteristics

The clam density manipulation was maintained during the experiment; in clam addition plots $(+C)$ median density was 6.0 core $^{-1}$ on $\mathrm{d} 2$ and 6.5 core $^{-1}$

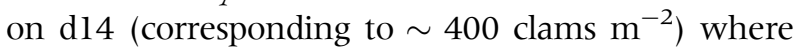
no clams were sampled in removal plots $(-\mathrm{C})$. The site average sediment organic content was $0.8 \pm 0.3 \%$, Chl- $a 3.0 \pm 0.3$ ug g dw ${ }^{-1}$ and phaeopigment $1.8 \pm 0.5 \mathrm{ug} \mathrm{g} \mathrm{dw^{-1 }}$ and median grain size ranged from 210 to $224 \mu \mathrm{m}$. Sediment characteristics were not affected by treatment (Clam or Ulva) or Time, regardless if the variables were tested collectively in a multivariate analysis or individually ( $p>0.20$; test results not shown).

Apart from clams, 36 macro-infaunal species or taxa were found $(n=96$ cores, excluding ostracods and nematodes); the community was dominated in both abundance and biomass by three species of amphipods and one maldanid head-down depositfeeding polychaete, $M$. stewartensis (see Table 1 and Table S1 for the most common and all species found, respectively). The most abundant species was a small $(<1 \mathrm{~mm})$ bivalve, Legrandina turneri.

PERMANOVA tests on the species composition (excluding clams, since they were manipulated) showed there was a significant effect of Ulva addition and a marginally significant interaction Ulva $\mathrm{x}$ Time (effects more pronounced on d14 (Table 2, Figure S2). PERMANOVA tests using each feeding group as a single response variable showed that suspension feeders were unaffected by the manipulations, while predators and scavengers were more abundant in Clam treatments (Table S4, Figure S3). For grazers, there was a marginally significant interaction between Clam and Ulva (Clams had a negative effect on grazers but not when Ulva was present), while deposit feeders had an Ulva x Time interaction (initially, $\mathrm{d} 2$, they were more abundant in Ulva plots) and generally more abundant when Clams were absent, Table S4, Figure S3).

\section{Effects of Clam Manipulation, Ulva Addition and Time on Ecosystem Functions}

The water temperature varied between the two sample dates with $10.8^{\circ} \mathrm{C}$ recorded at the start of incubations and $14.4^{\circ} \mathrm{C}$ at the end of the incubations on $\mathrm{d} 2$, whereas on $\mathrm{d} 14$, the temperature was $15.3^{\circ} \mathrm{C}$ and $14.2^{\circ} \mathrm{C}$ at the start and end of the incubations, respectively. There was a significant effect of both Clam and Ulva on SOC; however, these effects decreased over time (Figure 2, Table 2). There was no difference between Time or among treatments in GPP, but NPP was significantly lower when clams were present (Figure 2). There was a significant Clam $\times$ Time interaction for both $\mathrm{NH}_{4}{ }^{+}$and DRP efflux from sediment; clam removal resulted in lower efflux on $\mathrm{d} 2$ compared to d14 (Figure 2). For NOx, only the Time effect was significant (Table 2).

\section{Effects of Clam Manipulation on Resource Utilization in the Community (Isotope Niche)}

Clams in the non-amended Ulva plots $(-\mathrm{U})$ had a clearly different isotope signature relative to all other species, with particularly depleted $\delta^{13} \mathrm{C}$ values (Figure 3A, B, PERMANOVA results on differences among species in Table S5, Figure S4). The 
Table 2. Results of PERMANOVA Tests for Species Composition and Ecosystem Functions Using a ThreeWay Repeated Measures Design (see text)

\begin{tabular}{|c|c|c|c|c|c|}
\hline Source & $d f$ & MS & Pseudo-F & $p($ perm $)$ & Pair-wise tests \\
\hline \multicolumn{6}{|c|}{ Species composition } \\
\hline $\mathrm{C}$ & 1 & 391.77 & 1.67 & 0.0833 & \\
\hline $\mathrm{U}$ & 1 & 512.06 & 2.18 & 0.0169 & \\
\hline Time & 1 & 796.4 & 4.17 & 0.0002 & \\
\hline $\mathrm{C} \times \mathrm{U}$ & 1 & 348.95 & 1.48 & 0.1409 & \\
\hline $\mathrm{C} \times$ time & 1 & 163.76 & 0.86 & 0.5714 & \\
\hline $\mathrm{U} \times$ time & 1 & 345.62 & 1.81 & 0.0578 & \\
\hline Plot $(\mathrm{C} \times \mathrm{U})$ & 20 & 235.26 & 1.23 & 0.0500 & \\
\hline $\mathrm{C} \times \mathrm{U} \times$ time & 1 & 132.59 & 0.69 & 0.7342 & \\
\hline Residual & 20 & 190.84 & & & \\
\hline Total & 47 & & & & \\
\hline \multicolumn{6}{|l|}{ GPP } \\
\hline $\mathrm{C}$ & 1 & 0.656 & 1.115 & 0.3058 & \\
\hline $\mathrm{U}$ & 1 & 1.061 & 1.803 & 0.1947 & \\
\hline Time & 1 & 0.026 & 0.032 & 0.8618 & \\
\hline $\mathrm{C} \times \mathrm{U}$ & 1 & 0.424 & 0.720 & 0.4058 & \\
\hline $\mathrm{C} \times$ time & 1 & 0.366 & 0.449 & 0.4992 & \\
\hline$U \times$ time & 1 & 0.369 & 0.453 & 0.5089 & \\
\hline Plot $(\mathrm{C} \times \mathrm{U})$ & 20 & 0.588 & 0.722 & 0.7669 & \\
\hline $\mathrm{C} \times \mathrm{U} \times$ time & 1 & 0.748 & 0.915 & 0.3524 & \\
\hline Residual & 20 & 0.815 & & & \\
\hline Total & 47 & & & & \\
\hline \multicolumn{6}{|l|}{ NPP } \\
\hline $\mathrm{C}$ & 1 & 1.828 & 6.913 & 0.0176 & $-\mathrm{C}>+\mathrm{C}$ \\
\hline $\mathrm{U}$ & 1 & 0.321 & 1.213 & 0.2819 & \\
\hline Time & 1 & 3.546 & 9.312 & 0.0067 & d14 $>$ d2 \\
\hline $\mathrm{C} \times \mathrm{U}$ & 1 & 0.240 & 0.906 & 0.3498 & \\
\hline $\mathrm{C} \times$ time & 1 & 0.721 & 1.894 & 0.1813 & \\
\hline$U \times$ time & 1 & 0.214 & 0.563 & 0.4594 & \\
\hline Plot $(\mathrm{C} \times \mathrm{U})$ & 20 & 0.264 & 0.694 & 0.7916 & \\
\hline $\mathrm{C} \times \mathrm{U} \times$ time & 1 & 0.283 & 0.742 & 0.3967 & \\
\hline Residual & 20 & 0.381 & & & \\
\hline Total & 47 & & & & \\
\hline \multicolumn{6}{|l|}{ SOC } \\
\hline $\mathrm{C}$ & 1 & 4.674 & 11.87 & 0.0018 & $+\mathrm{C}>-\mathrm{C}$ \\
\hline U & 1 & 2.548 & 6.47 & 0.0193 & $+\mathrm{U}>-\mathbf{U}$ \\
\hline Time & 1 & 2.961 & 7.00 & 0.0157 & d2 $>$ d14 \\
\hline $\mathrm{C} \times \mathrm{U}$ & 1 & 0.026 & 0.07 & 0.7975 & \\
\hline $\mathrm{C} \times$ time & 1 & 0.060 & 0.14 & 0.7125 & \\
\hline $\mathrm{U} \times$ time & 1 & 1.146 & 2.71 & 0.1205 & \\
\hline Plot $(\mathrm{C} \times \mathrm{U})$ & 20 & 0.394 & 0.93 & 0.5717 & \\
\hline $\mathrm{C} \times \mathrm{U} \times$ time & 1 & 0.110 & 0.26 & 0.6139 & \\
\hline Residual & 20 & 0.423 & & & \\
\hline Total & 47 & & & & \\
\hline \multicolumn{6}{|l|}{ NH4+ } \\
\hline C & 1 & 5643.4 & 6.996 & 0.0147 & \\
\hline U & 1 & 1087.6 & 1.348 & 0.2574 & \\
\hline Time & 1 & 18425 & 19.063 & 0.0004 & \\
\hline $\mathrm{C} \times \mathrm{U}$ & 1 & 9.063 & 0.011 & 0.9171 & \\
\hline $\mathrm{C} \times$ time & 1 & 6887.9 & 7.126 & 0.0128 & d2: $+C>-C ; d 14:+C=-C$ \\
\hline$U \times$ time & 1 & 1997.6 & 2.067 & 0.1646 & \\
\hline Plot $(\mathrm{C} \times \mathrm{U})$ & 20 & 806.6 & 0.835 & 0.6637 & \\
\hline $\mathrm{C} \times \mathrm{U} \times$ time & 1 & 994.5 & 1.029 & 0.3251 & \\
\hline
\end{tabular}


Table 2. continued

\begin{tabular}{|c|c|c|c|c|c|}
\hline Source & $d f$ & MS & Pseudo-F & $p($ perm $)$ & Pair-wise tests \\
\hline Residual & 20 & 966.5 & & & \\
\hline Total & 47 & & & & \\
\hline \multicolumn{6}{|l|}{ NOx } \\
\hline $\mathrm{C}$ & 1 & 26.153 & 0.934 & 0.3451 & \\
\hline $\mathrm{U}$ & 1 & 27.724 & 0.990 & 0.3352 & \\
\hline Time & 1 & 917.32 & 15.723 & 0.0017 & $\mathrm{~d} 2>\mathrm{d} 14$ \\
\hline $\mathrm{C} \times \mathrm{U}$ & 1 & 0.117 & 0.004 & 0.953 & \\
\hline $\mathrm{C} \times$ time & 1 & 13.441 & 0.230 & 0.6431 & \\
\hline $\mathrm{U} \times$ time & 1 & 31.665 & 0.543 & 0.4726 & \\
\hline Plot $(\mathrm{C} \times \mathrm{U})$ & 20 & 27.995 & 0.480 & 0.9681 & \\
\hline $\mathrm{C} \times \mathrm{U} \times$ time & 1 & 28.783 & 0.493 & 0.4844 & \\
\hline Residual & 20 & 58.343 & & & \\
\hline Total & 47 & & & & \\
\hline \multicolumn{6}{|l|}{ DRP } \\
\hline $\mathrm{C}$ & 1 & 36.332 & 0.608 & 0.4526 & \\
\hline $\mathrm{U}$ & 1 & 46.295 & 0.775 & 0.3884 & \\
\hline Time & 1 & 3452.8 & 62.822 & 0.0001 & \\
\hline $\mathrm{C} \times \mathrm{U}$ & 1 & 92.814 & 1.554 & 0.2306 & \\
\hline $\mathrm{C} \times$ Time & 1 & 400.22 & 7.282 & 0.0142 & d2: $+C>-C ; d 14:+C=-C$ \\
\hline $\mathrm{U} \times$ Time & 1 & 60.687 & 1.042 & 0.3093 & \\
\hline Plot $(\mathrm{C} \times \mathrm{U})$ & 20 & 59.741 & 1.087 & 0.4213 & \\
\hline $\mathrm{C} \times \mathrm{U} \times$ time & 1 & 27.905 & 0.508 & 0.4908 & \\
\hline Residual & 20 & 54.963 & & & \\
\hline Total & 47 & & & & \\
\hline \multicolumn{6}{|c|}{$\delta^{15} \mathrm{~N}$ sediment $(+\mathrm{U})$} \\
\hline $\mathrm{C}$ & 1 & 9407.2 & 3.181 & 0.1244 & \\
\hline Time & 1 & 66220 & 15.552 & 0.0036 & $\mathrm{~d} 2>\mathrm{d} 14$ \\
\hline Plot $(\mathrm{C})$ & 10 & 2957.6 & 0.695 & 0.7441 & \\
\hline $\mathrm{C} \times$ time & 1 & 10757 & 2.526 & 0.1404 & \\
\hline Residual & 10 & 4258 & & & \\
\hline Total & 23 & & & & \\
\hline \multicolumn{6}{|c|}{$\delta^{15} \mathrm{~N}$ and $\delta^{13} \mathrm{C}$ sub-surface feeder $(+\mathrm{U})$} \\
\hline $\mathrm{C}$ & 1 & 52.718 & 0.145 & 0.7159 & \\
\hline Time & 1 & 6772.3 & 12.831 & 0.006 & $\mathrm{~d} 14>\mathrm{d} 2$ \\
\hline Plot $(\mathrm{C})$ & 10 & 362.63 & 0.687 & 0.7228 & \\
\hline $\mathrm{C} \times$ time & 1 & 1.22 & 0.002 & 0.9682 & \\
\hline Residual & 10 & 527.79 & & & \\
\hline Total & 23 & & & & \\
\hline
\end{tabular}

The three fixed factors were; (1) clam manipulation $(C ; 2$ levels: $+C,-C)$, (2) Ulva detritus addition $(U ; 2$ levels: $+U,-U)$ and Time (sampling day; 2 levels; 2 and d14) with plots nested as a random factor within the manipulated treatments. For enriched isotope data $\left(\delta^{15} N\right.$ in sediment and $\delta^{15} N$ and $\delta^{13} C$ in the sub-surface feeding polychaete Macroclymenella stewartensis) from the $+U$ treatments the repeated measure design consisted of the fixed factors Clam and Time. Significant results are indicated in bold $(p<0.05)$, and pair-wise post hoc results are given for significant interactions. Main effects are only considered in the absence of a statistically significant interaction. SOC sediment oxygen consumption ( $m$ mol $\left.\mathrm{O}_{2} \mathrm{~m}^{-2} \mathrm{~h}^{-1}\right)$, NPP net primary production (mmol $\left.\mathrm{O}_{2} \mathrm{~m}^{-2} \mathrm{~h}^{-1}\right)$, GPP gross primary production $\left(m m o l \mathrm{O}_{2} \mathrm{~m}^{-2} \mathrm{~h}^{-1}\right)$, NH${ }_{4}^{+}$ammonium efflux $\left(\mu \mathrm{mol} \mathrm{m} \mathrm{m}^{-2} \mathrm{~h}^{-1}\right)$, DPR dissolved reactive phosphate efflux $\left(\mu \mathrm{mol} \mathrm{m} \mathrm{m}^{-2} \mathrm{~h}^{-1}\right)$. Analyses on abundance of feeding traits are shown in Table S3.

free-living predatory/omnivorous anemone $E d$ wardsia neozelanica and the nereidid polychaete had the highest $\delta^{15} \mathrm{~N}$ values, and the amphipods $T$. hurelyi and $W$. brevirostris had more enriched $\delta^{13} \mathrm{C}$ values than several of the other species (Table S5, Figure S4).

Removal of clams resulted in a significantly smaller isotopic niche, as hypothesized, measured both from total convex hull area (Figure 3, 60\%) or Bayesian ellipses $\left(\mathrm{SEA}_{\mathrm{B}}\right.$, Figure $\left.\mathrm{S} 4\right)$. All Layman metrics are larger when clams are present (supplementary Table S6). Considering just the infaunal species found in both treatments $(+\mathrm{C}-\mathrm{U},-\mathrm{C}-\mathrm{U})$, the niche area was shifted to more enriched $\delta^{13} \mathrm{C}$ values in the treatment without clams (paired $t$ test, $t=4.22, p=0.004, n=8$ ), as hypothesized. SEA 


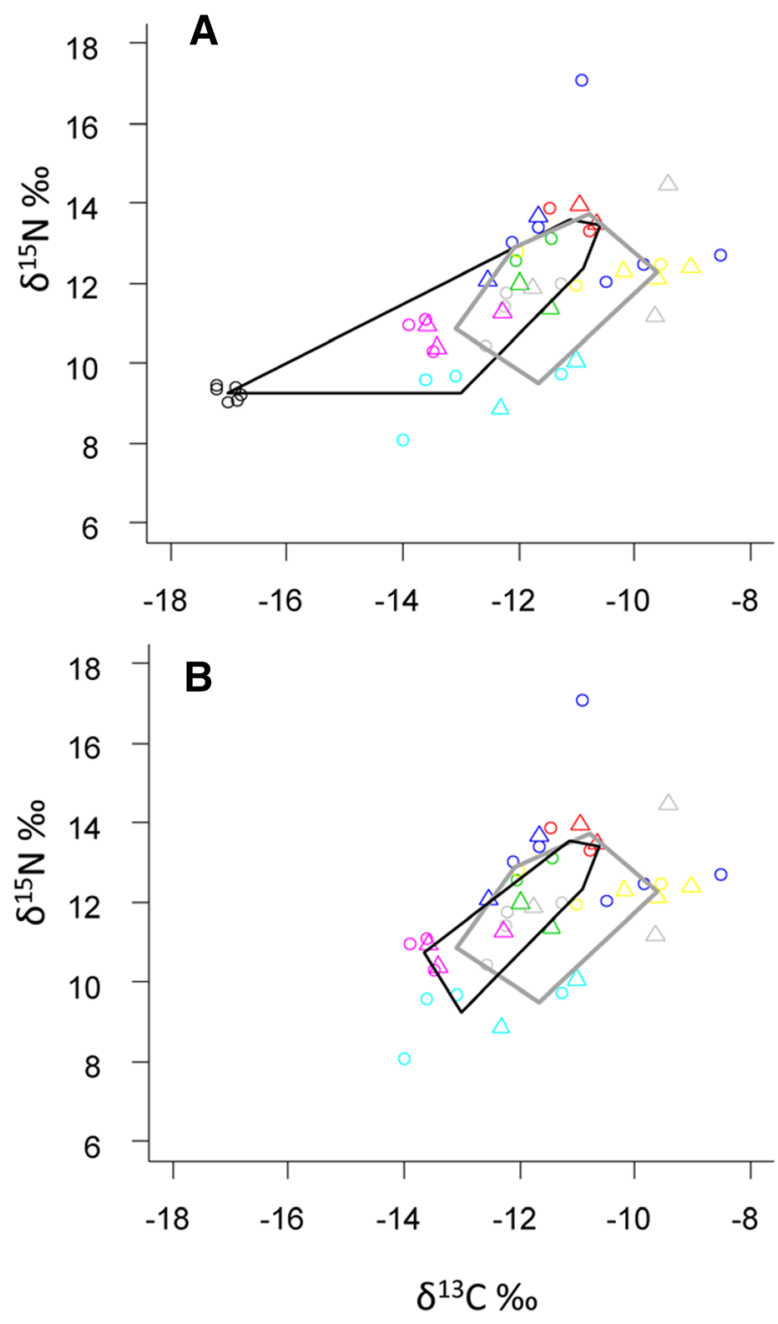

Figure 3. Isotope biplots illustrating the community isotope niche (convex hull area) for natural abundance isotope data in no Ulva treatments of common taxa in plots with clams $(+\mathrm{C}-\mathrm{U}$; circles, black line) and without clams ( $-\mathrm{C}-\mathrm{U}$; triangles, grey line) three weeks after clam manipulation. A Includes Austrovenus stutchburyi in the $+\mathrm{C}-\mathrm{U}$ community, whereas in $\mathbf{B}$ the same data is replotted omitting $A$. stutchburyi to enable a direct comparison with the $-\mathrm{C}-\mathrm{U}$ community (note the change in $x$-scale). See Table S5 for other Layman niche metrics and Figure S4 for Standard Ellipse Area with Bayesian credible intervals. Differences in isotope composition among species (that is, the different colours, species codes in Figure S4) are reported in PERMANOVA Table S5.

overlap calculations show that of total niche area occupied, the shared isotopic space between the two treatments is $25 \%$ when clams in the $+\mathrm{C}-\mathrm{U}$ treatment are included and $35 \%$ when they are excluded (Figure S4). The hypothesized expansion of the infaunal feeding niche following clam removal when only infauna are considered was $58 \%$ for convex hull area (Table S6), but $\mathrm{SEA}_{\mathrm{B}}$ values
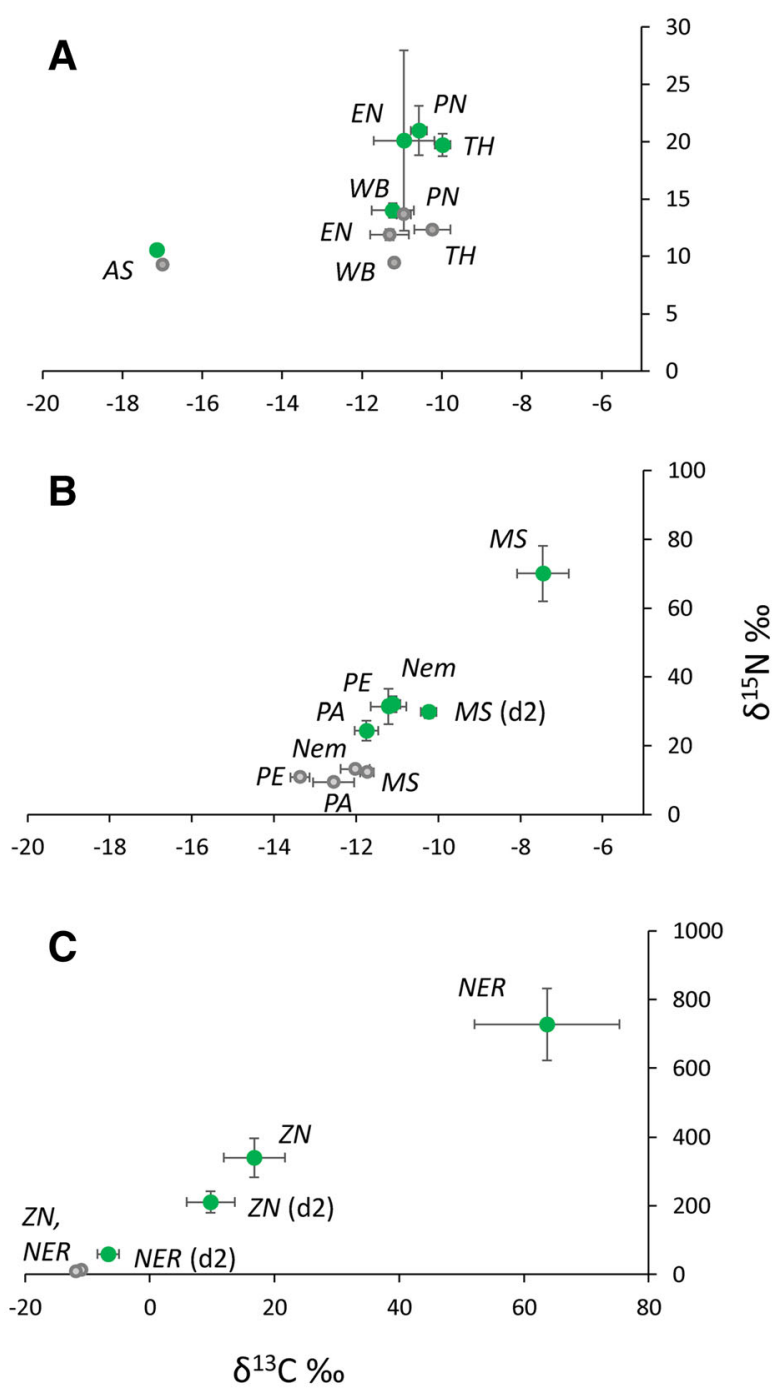

Figure 4. A-C Natural isotope abundance (-U treatments; grey symbols) and enriched isotope data (+U treatments, green symbols) for macrofauna on d 14 after Ulva addition (and $\mathrm{d} 2$ for three of the species); values are mean $\pm \mathrm{SE}$, averaged between $+\mathrm{C}$ and $-\mathrm{C}$ treatments to improve readability (as there was no significant clam effect, see Table 2 and Table S8). A Species with low isotope enrichment $(\mathrm{AS}=$ Austrovenus stutchburyi (clams), the amphipods Waitangi brevirostris $=\mathrm{WB}, \quad$ Torridoharpinia hurleyi $=\mathrm{TH}$, and Paracalliope novizealandiae $=\mathrm{PN}$ and the anemone Edwardsia neozelanica $=$ EN (see Table S7 for statistical comparisons to $-\mathrm{U}$ treatments). B Species with medium isotope enrichment (nematodes $=$ Nem, the polychaetes Macroclymenella stewartensis = MS and Prionospio aucklandica $=\mathrm{PA}$, and the amphipod Paracorophium excavatum $=\mathrm{PE}$ ) and $\mathbf{C}$ species with high enrichment (the nereidid polychaete $=$ NER and the tanaidacean Zeuxo novaezealandiae $=\mathrm{ZN})$.

had largely overlapping credible intervals (Figure S4). 


\section{Fate of Ulva-Derived Nitrogen: Effects of Clam and Time}

Ulva fragments were recovered from the sediment in detrital addition $(+\mathrm{U})$ plots on $\mathrm{d} 2$ and $\mathrm{d} 14$, but were notably smaller on dil4 (pers. obs.). No Ulva fragments were observed in non-amended $(-\mathrm{U})$ plots, indicating a low likelihood of isotopic contamination. The $\delta^{15} \mathrm{~N}$ value of the surface sediment decreased significantly between $\mathrm{d} 2$ and $\mathrm{d} 14$ (from $\sim 150 \%$ on d 2 to $\sim 50 \%$ on d 14 , Figure S 5 ), but there was no effect of Clams on sediment $\delta^{15} \mathrm{~N}$ and the Clam $\mathrm{x}$ Time interaction was also not significant (Table 2). The $\delta^{15} \mathrm{~N}$ values correspond to a recovery of less than $1 \%$ of added Ulva-N on $\mathrm{d} 2$, demonstrating that most of the added Ulva was lost from the plots due to physical resuspension during the first tidal cycle (because it was not recovered in the fauna to such an extent-see below).

On d14, all eleven species selected for isotope analyses (Table 1) showed higher $\delta^{15} \mathrm{~N}$ (+U plots), compared to natural abundance in -U plots (Figure 4, Table S7). For the four species with lower levels of $\delta^{15} \mathrm{~N}$ enrichment (Figure $4 \mathrm{~A}$ ), $\delta^{13} \mathrm{C}$ was not significantly different between $+\mathrm{U}$ and $-\mathrm{U}$ treatments (Table S7), although Edwardsia neozelanica, $W$. brevirostris and $T$. hurleyi had on average more enriched ${ }^{13} \mathrm{C}$ values in $+\mathrm{U}$ plots (Figure $4 \mathrm{~A}$ ) and all species except $A$. stutchbury showed a positive correlation between $\delta^{15} \mathrm{~N}$ and $\delta^{13} \mathrm{C}$ (Table S3). Nereididae and Z. novaezealandiae had (much) higher isotope enrichment than the other species (Figure 4C). There was no effect of clam removal on ${ }^{15} \mathrm{~N}$ and ${ }^{13} \mathrm{C}$ enrichment in these two or the other species (Table S8, Table 2$) \cdot{ }^{15} \mathrm{~N}$ enrichment was measurable on $\mathrm{d} 2$ in the three species analysed: Nereididae, $Z$. novaezealandiae and $M$. stewartensis (Figure 5B, C); for $Z$. novaezealandiae and $M$. stewartensis the ${ }^{15} \mathrm{~N}$ enrichment was about twice as high on dl4 but for Nereididae the enrichment was 12 -fold higher on d 14 compared to $\mathrm{d} 2$.

Summing together the uptake values with respect to species-specific ${ }^{15} \mathrm{~N}$ enrichment, $\mathrm{N}$ content, individual biomass and densities on d14, the total uptake of Ulva-derived nitrogen was significantly higher in the $+\mathrm{C}+\mathrm{U}$ treatment (when A. stutchburyi were included in the calculation) compared to the $-\mathrm{C}+\mathrm{U}$ treatment (Pseudo- $F_{1,11}=6.81, p=0.034$, Figure 5). When A. stutchburyi is omitted from the infaunal community uptake in the $+\mathrm{C}+\mathrm{U}$ plots, infaunal community uptake in the $+\mathrm{C}+\mathrm{U}$ treatment is similar to the $-\mathrm{C}+\mathrm{U}$ community (Pseudo- $F_{1}$, $\left.{ }_{11}=0.12, p=0.76\right)$. In Figure 5 it is clear that, apart from when clams (A. stutchburyi) were present

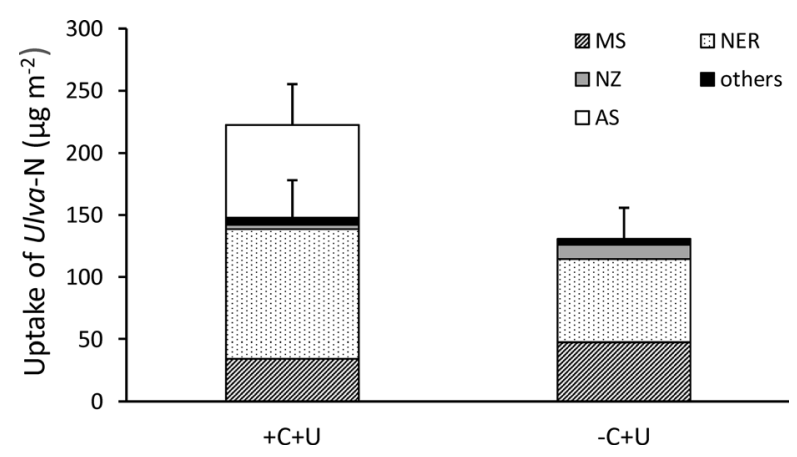

Figure 5. Total community macrofaunal uptake of Ulva nitrogen per $\mathrm{m}^{2}$ on $14 \mathrm{~d}$ after addition (d14) demonstrating the importance of three species/taxa for community uptake; A. stutchburyi (AS) Nereididae (NER) and $M$. stewartensis (MS). ZN refers to Zeuxo novaezealandiae and the category "others" includes the four species of amphipods, one polychaete and one anemone (see Table 1, Figure 4) as well as the nematode community. Values represent the mean $+\mathrm{SE}$. The difference between the $+\mathrm{C}$ and $-\mathrm{C}$ communities is significant, but uptake of infauna (excluding AS) between $+\mathrm{C}+\mathrm{U}$ and $-\mathrm{C}+\mathrm{U}$ treatments is not significant (see text).

in the community, three species contributed most to Ulva-N uptake (expressed as $\mu \mathrm{g} \mathrm{m}^{-2}$ ); Nereididae, M. stewartensis and Z. novaezealandiae. The total community uptake corresponded to $5 \pm 2.5 \%$ $(-\mathrm{C}+\mathrm{U}$, mean $\pm \mathrm{SD}, n=6)$ or $9 \pm 3 \%(+\mathrm{C}+\mathrm{U}$, mean $\pm \mathrm{SD}, n=6$ ) of the Ulva-N left in the sediment on $\mathrm{d} 2$.

\section{Discussion}

This multifactorial field experiment demonstrates that large bivalves (the clam Austrovenus stutchburyi) from intertidal habitats determine both carbon pathways in the deposit-feeding community and community uptake of nitrogen of macroalgal origin. The fact that other species cannot compensate for the loss of $A$. stutchburyi during the timeframe of this study demonstrates its role as a key species in estuarine ecosystems; its loss will result in reduced resource utilization by the benthic community and in reduced trophic transfer of detrital subsidies from macroalgae. As these shellfish are subject to intense commercial and recreational harvesting in some New Zealand estuaries (Adkins and others 2014), and as eutrophication increases the occurrence of nuisance macroalgal blooms (for example, Marsden and Bressington 2009), the loss of clams may exacerbate coastal eutrophication by reducing faunal incorporation of nutrients from decomposing algae detritus and augment organic matter 
loading in estuaries (see, for example, increased efflux of phosphate on $\mathrm{d} 2$ when clams are absent but Ulva added).

\section{Effects on Resource Utilization in the Absence of Excess Macroalgae}

We hypothesized that removal of clams would affect other species isotope composition through altered trophic interactions. The distinct depleted carbon isotope signal in A. stutchburyi in the treatments without added Ulva detritus indicates that it feeds largely on pelagic phytoplankton, in agreement with it being a suspension feeder (Sandwell and others 2009). Accordingly, the other infaunal species had significantly more depleted ${ }^{13} \mathrm{C}$ values $(0.5-1 \%$ o when $A$. stutchburyi was present compared to clam removal plots, supporting the direct effects of clams on the diet of other species through biodeposit (food source) production for deposit feeders (Norkko and others 2001). Without clams, less carbon of pelagic origin will be channelled into the benthic food web. Because pelagic microalgae are a highly nutritious food source compared to sedimentary organic matter or the more refractory macroalgal material, such a shift may have potentially negative consequences on growth rates of infauna (Cruz-Rivera and Hay 2001; Yin and others 2019). This could eventually lead to niche expansion of the remaining infauna as hypothesized and observed (58\% larger convex hull area when clams were absent), although this trend was not statistically significant using the robust but insensitive $\mathrm{SEA}_{\mathrm{B}}$ approach which ignores species identity. A longer experimental duration at these rather low temperatures and hence growth conditions for infauna would likely have reduced the variability in reaching isotope equilibrium among and within species (Kaufman and others 2008).

\section{Effects on Uptake of Macroalgae-Derived Detritus}

In the Ulva addition treatments, nitrogen of Ulva origin was quickly incorporated (uptake evident in macrofauna on $\mathrm{d} 2$ ) and at d14, all tested species showed significant uptake. The tanaidacean grazer Zeuxo novaezealandiae had highly enriched ${ }^{13} \mathrm{C}$ and ${ }^{15} \mathrm{~N}$ values on $\mathrm{d} 2$, indicating direct feeding on the Ulva fragments. Interestingly, the highest uptake of Ulva-derived nitrogen was found for nereidids, and the much higher uptake for nereidids on dl4 compared to $\mathrm{d} 2$ relative to the other species also measured on both days might be explained by a predatory feeding mode, bioaccumulating the ${ }^{15} \mathrm{~N}$ - enriched organic matter. Species with low uptake of Ulva-derived nutrients (that is, the amphipods Waitangi brevirostris and Torridoharpinia hurleyi), might feed only indirectly on the added detritus by ingesting other species faeces or relying mainly on aged organic matter rather than on freshly added detritus (Rudnick 1989; Byrén and others 2006).

Suspension-feeding A. stutchburyi was not expected to assimilate the added detritus fragments, but resuspension of the smaller fragments on dl4 could have enabled ingestion and hence uptake. Macroalgal uptake by clams has indeed previously been suggested in this inlet using natural stable isotope mixing models (for example, Leduc and others 2006); here, the ${ }^{15} \mathrm{~N}$ enrichment confirms these indications; however, there was no similar enrichment in ${ }^{13} \mathrm{C}$ (indicating no uptake of Ulva-derived carbon). It is likely that most of the isotope enrichment in the Ulva cells would have pooled mainly in the cytosole rather than being incorporated into the cell wall, suggesting that our experiment best reflects the initial decaying phase of fresh macroalgal detritus and that clams instead feed on microphytobenthos (MPB) which assimilated leaking ${ }^{15} \mathrm{~N}$ from the Ulva. Ulva detritus leaches dissolved organic nitrogen (Tyler and others 2001) into the sediment porewater which can undergo ammonification/nitrification through bacterial activity (Devol 2015; Säwström and others 2016) and stimulate efflux of remineralized dissolved inorganic nitrogen (Crawshaw and others 2019) that supports MPB production. MPB concentrations in sediment were too low for separation and isotope analysis in the current study, but other isotope studies have shown that suspension-feeding clams feed on resuspended MPB (Kang and others 2006; Christianen and others 2017).

Indirect positive clam effects on per capita uptake (that is, isotope enrichment) of the added Ulva material by other benthic species was expected (from bioturbation) but not found in this study. In a laboratory experiment from the North Island of New Zealand, increasing densities of $A$. stutchburyi were linked to higher uptake in two deposit-feeding species, a tellinid clam and a capitellid polychaete (Karlson and others 2016). These two species were, however, not encountered in the current study and no positive or negative effect of clam manipulation on per capita uptake was found for any of the 10 species tested. (Variation was very large, however, probably reflecting the challenge of achieving an even distribution of enriched material in a field setting and hence encounter rates of fauna.) Since several of the species had a higher abundance when clams were absent, uptake scaled 
for abundance and biomass (Figure 5) was, however, higher, for example, $Z$. novaezealandiae (threefold higher), while the opposite pattern was found for Nereididae (higher total uptake when clams were present). Clams themselves had a small but significant ${ }^{15} \mathrm{~N}$ enrichment (low per capita uptake), but due to their large biomass this uptake translates into a considerable amount of Ulva-derived nitrogen (although not carbon) being tied up in their biomass. Importance of large bivalves for ecosystem functions such as nutrient efflux from sediments (Norkko and others 2013) is well known, but this study demonstrates that $A$. stutchburyi is indeed a key species also regarding food web effects. Loss of clams reduces trophic transfer of detrital subsidies from macroalgae, increasing the ecosystem's sensitivity to eutrophication, since algal-derived nutrients will ultimately be released to the water column and potentially fuel more production rather than being tied up in faunal tissue. Although the clams themselves excrete large amounts of $\mathrm{NH}_{4}^{+}$(Sandwell and other 2009; Woodin and others 2016), discussed as a problem for clam aquaculture (Murphy and others 2016), clams can moderate nutrient efflux of detrital organic matter; for example, the phosphate (DRP) efflux from sediment was significantly higher when Ulva was added in clam removal plots (Figure 2, d2 only), but not when clams were present.

\section{Effects on Infaunal Species Composition}

We predicted that the removal of clams and addition of detritus would lead to changes in the infaunal community composition due to decreases in clam-associated fauna and/or increases in opportunistic mobile species (compare Cesar and Frid 2009). We found that mainly macroalgal addition had an effect on species composition. Summing together all species with similar feeding modes (Greenfield and others 2016), it was, however, found that deposit feeders and to some extent grazers were significantly more abundant when clams were absent (for example, M. stewartensis and $Z$. novaezealandiae as mentioned above), while the opposite was true for predators and scavengers (for example, Nereididae). Grazers and deposit feeders were initially more abundant when Ulva was added, but declined over time likely due to decreasing amounts of detritus (that is, lower amounts left in sediment on d14). Although positive (or neutral) effects on infauna densities from removing clams has been reported (Hewitt and Cummings 2013), other removal experiments in the North Island have shown that the presence of clams is associated with a higher density of sub-surface deposit-feeding polychaete species (Thrush and others 2006). These polychaetes (several taxa) were, however, not encountered in our study, supporting the context dependency of clam removal observed here when algal detritus was present or absent (interaction effect significant for grazers). Further, clams on the North Island are generally smaller than South Island conspecifics (Wells and other 2019), potentially leading to differential effects on associated fauna. In our study, the two most abundant amphipods, Paracorophium excavatum and T. hurleyi had their highest abundance in the treatments without clams $(-\mathrm{C}+\mathrm{U}$ and $-\mathrm{C}-\mathrm{U}$, respectively). The former is considered a suspension feeder, while the latter is a deposit feeder/scavenger (Greenfield and others 2016); the high natural abundance $\delta^{15} \mathrm{~N}$ values for $T$. hurleyi support the scavenger/deposit feeder feeding mode. The similar and relatively high $\delta^{13} \mathrm{C}$ values for both species, the rather high uptake of added Ulva-derived nutrients by P. excavatum and the higher abundance of $P$. excavatum in the Ulva treatment suggest, however, that the diet of $P$. excavatum consists of (resuspended) detritus and not pelagic phytoplankton. As a likely result, the Ulva amended plots without competition for food from clams would have been an attractive habitat for these mobile species, although an alternative explanation is lower predation by, for example, Nereididae which were more abundant when clams were present.

\section{Effects on Ecosystem Functions}

We predicted that, in addition to the direct metabolic effects by the clams, addition of detrital macroalgae would lead to increased nutrient regeneration and consequently increased primary production from microphytobenthos in the sediment surface (compare Gladstone-Gallagher and others 2016). We also expected that clam respiration and the additional organic matter undergoing degradation by bacteria would increase benthic metabolism (SOC). We found that presence of clams and the Ulva addition indeed enhanced oxygen consumption in the sediment, but that only clams and not Ulva had an effect on nutrient regeneration (with the exception of phosphate efflux on $\mathrm{d} 2$ being higher in the Ulva plots when clams were absent). The clam effect was, however, transient (no effect on di4) and with no effect on gross primary production (GPP). This is in contrast to a previous clam removal experiment from the North Island where effects on GPP were more pronounced in sandy sediments (the study site at 
Papanui is a dynamic nutrient-poor sandflat) compared to muddy sediments (Jones and others 2011). However, community composition in the other studies is very different from that at Papanui Inlet, which was dominated by amphipods with few polychaetes. The clam removal effect on microphytobenthic biomass and primary production is difficult to predict due to complex feedbacks (for example, Thrush and others 2006, 2014) with elevated nutrient availability from clam excretion and indirect effects on sediment conditions (Sandwell and others 2009; Woodin and others 2016). Physical disturbance from movement of the clams and ingestion of resuspended microphytes (as indicated by the selective uptake of ${ }^{15} \mathrm{~N}$ only in clams compared to all other species in this study, suggesting that added Ulva leak ${ }^{15} \mathrm{~N}$ as $\mathrm{NH}_{4}{ }^{+}$which is taken up by MPB as discussed above) is likely to decrease benthic microalgal biomass (Thrush and others 2006). The similar sediment chlorophyll concentrations among treatments suggest that microphytobenthic standing crop was not affected by any of the manipulations, although we cannot rule out potential higher grazing pressure by clams themselves (through resuspension of MPB) and by the larger abundance of grazers in the $-\mathrm{C}$ treatments, where physical disturbance and ingestion by clams are avoided (Jones and others 2017).

The increased oxygen consumption in the Ulva treatments could be partly because of enhanced bacterial respiration from mineralization of the detritus but also from the larger abundance of deposit feeders (respiration effects) in the $-\mathrm{C}+\mathrm{U}$ treatment compared to other treatments. The halflife of macroalgal (Ecklonia radiata) detritus is less than 3 days in the warmer North Island sediments (Gladstone-Gallagher and others 2016), suggesting that most of the added detritus should have been gone at $\mathrm{d} 14$ in this experiment, explaining why no significant effects on nutrient fluxes or primary production were measured at that time. Also, the low recovery of added Ulva detritus after the first tidal cycle suggests some loss of the detritus at this site. Tiny Ulva fragments, visible by eye, were, however, encountered in the sediment samples (in $+\mathrm{U}$ plots only) on termination of the experiment and the nitrogen isotope composition revealed that about a third what was left in surface sediment on $\mathrm{d} 2$ was still present in sediment on d 14 (regardless of clam presence) indicating a considerably slower half-life in the sandy Papanui sediments. The similar per capita uptake of Ulva-nitrogen in the headdown deposit-feeding species Macroclymenella stewartensis between the $+\mathrm{C}+\mathrm{U}$ and $-\mathrm{C}+\mathrm{U}$ treatments suggests that there is no clam removal effect on detrital recovery in sediment at deeper sediment either.

\section{ConClusion}

This study combines trophic resource use quantified by isotope niche metrics with in situ isotope labelling and solute flux measurements in a multifactorial field experiment with temporal resolution. Overall, our work indicates that human activities that alter species composition (overharvesting of large bivalves) and the amount of macroalgal detritus (eutrophication) will impact the structure and function of soft-sediment ecosystems. Their combined effects will result in less efficient pelagic-benthic coupling to the infauna and less nutrients of macroalgal origin being tied up in the biomass of long-lived clams. Instead loss of clams could lead to an accumulation of nutrients and organic matter in the system. Management should take into account the positive effects of clams in counteracting eutrophication, not only for their role in water quality through suspension-feeding but also for their direct role in channelling pelagic resources to infauna and indirect role in trophic transfer of macroalgal-derived nutrients mineralized by bacteria, assimilated by microphytobenthos and then incorporated by clams in benthic communities. Here, we demonstrate that overharvesting of a key bivalve can have both direct and more subtle indirect effects on the ability of the ecosystem to process detrital subsidies, an ecosystem function that underlies resilience to eutrophication.

\section{ACKNOWLEDGEMENTS}

Open access funding provided by Stockholm University. This study was funded by a postdoctoral scholarship by the Swedish Research Council (VR) to AMLK (contract 623-2010-600). Performance Based Research Funds to CS supported stable isotope costs. A. Lohrer (NIWA) kindly provided the benthic chambers. Students from Otago University (S. Schüller, E. Miller, S. Cunningham) and staff at Portobello Marine Laboratory (D. Wilson, A. Zhou) and Waikato University (W Powrie) assisted with field work. D Bartley helped with field work and sorting of samples and was supported by an Endeavour Teaching Fellowship. Sediment samples were prepared for analyses by H. Needham (Waikato University). We thank M. J. Anderson (Massey University and PRIMER-e) for statistical advice and C. Lienart (Stockholm University) for inspiring discussions and several anonymous reviewers for 
their valuable comments on earlier versions of this manuscript.

\section{OPEN ACCESS}

This article is licensed under a Creative Commons Attribution 4.0 International License, which permits use, sharing, adaptation, distribution and reproduction in any medium or format, as long as you give appropriate credit to the original author(s) and the source, provide a link to the Creative Commons licence, and indicate if changes were made. The images or other third party material in this article are included in the article's Creative Commons licence, unless indicated otherwise in a credit line to the material. If material is not included in the article's Creative Commons licence and your intended use is not permitted by statutory regulation or exceeds the permitted use, you will need to obtain permission directly from the copyright holder. To view a copy of this licence, visit http://creativecommons.org/licenses/by/4.0/.

\section{REFERENCES}

Adkins SC, Marsden ID, Pirker JG. 2014. Variation in population structure and density of Austrovenus stutchburyi (Veneridae) from Canterbury, New Zealand. J Shellfish Res 33:343-54.

Albrecht N, Vennell R. 2007. Tides in two constricted New Zealand lagoons. N Z J Mar Freshw Res 41:103-18.

Anderson MJ, Gorley RN, Clarke KR 2008. PERMANOVA+ for PRIMER. Guide to software and statistical methods. PRIMERE: Plymouth, UK, p 214.

Blair NE, Levin LA, DeMaster DJ, Plaia G. 1996. The short-term fate of fresh algal carbon in continental slope sediments. Limnol Oceanogr 41:1208-19.

Byrén L, Ejdung G, Elmgren R. 2006. The use of sedimentary organic matter by deposit-feeding amphipods, studied using three isotope tracers. Mar Ecol Prog Ser 313:135-43.

Cardinale BJ, Duffy JE, Gonzalez A, Hooper DU, Perrings C, Venail P et al. 2012. Biodiversity loss and its impact on humanity. Nature 486:59-67.

Cesar CP, Frid CLJ. 2009. Effects of experimental small-scale cockle (Cerastoderma edule L.) fishing on ecosystem function. Mar Ecol 30:123-37.

Christianen MJA, Middelburg JJ, Holthuijsen SJ, Jouta J, Compton TJ, van der Heide T, Piersma T, Sinninghe Damste JS, van der Veer HW, Shouten S, Olff H. 2017. Benthic primary producers are key to sustain the Wadden Sea food web: stable carbon isotope analysis at landscape scale. Ecology 98:1498-512.

Crawshaw J, O'Meara T, Savage C, Thomson B, Baltar F, Thrush SF. 2019. Source of organic detritus and bivalve biomass influences nitrogen cycling and extracellular enzyme activity in estuary sediments. Biogeochem 145:315-35.

Cruz-Rivera E, Hay ME. 2001. Macroalgal traits and the feeding and fitness of an herbivorous amphipod: the roles of selectivity, mixing, and compensation. Mar Ecol Prog Ser 218:24966.
Devol AH. 2015. Denitrification, anammox, and N2 production in marine sediments. Annu Rev Mar Sci 7:403-23.

Duffy JE, Cardinale BJ, France KE, McIntyre PB, Thebault E, Loreau M. 2007. The functional role of biodiversity in ecosystems: incorporating trophic complexity. Ecol Lett 10:522-38.

Gladstone-Gallagher RV, Lohrer AM, Lundquist CJ, Pilditch CA. 2016. Effects of detrital subsidies on soft-sediment ecosystem function are transient and source-dependent. PLOS ONE 11(5):e0154790.

Greenfield BL, Kraan C, Pilditch CA, Thrush SF. 2016. Mapping functional groups can provide insight into ecosystem functioning and potential resilience of intertidal sandflats. Mar Ecol Prog Ser 548:1-10.

Herman PMJ, Middelburg JJ, Widdows J, Lucas CH, Heip CHR. 2000. Stable isotopes as trophic tracers: combining field sampling and manipulative labelling of food resources for macrobenthos. Mar Ecol Prog Ser 204:79-92.

Hewitt JE, Thrush SF, Dayton PK, Bonsdorff E. 2007. The effect of spatial and temporal heterogeneity on the design and analysis of empirical studies of scale-dependent systems. Am Nat 169:398-408.

Hewitt JE, Cummings VJ. 2013. Context-dependent success of restoration of a key species, biodiversity and community composition. Mar Ecol Prog Ser 479:63-73.

Hiddink JG, Wynter Davies T, Perkins M, Machairopoulou M, Neill SP. 2009. Context dependency of relationships between biodiversity and ecosystem functioning is different for multiple ecosystem functions. Oikos 118:1892-900.

Jackson AL, Inger R, Parnell AC, Bearhop S. 2011 . Comparing isotopic niche widths among and within communities: SIBER-stable isotope Bayesian ellipses in R. J Anim Ecol 80:595-602.

Jones HFE, Pilditch CA, Bruesewitz DA, Lohrer AM. 2011. Sedimentary environment influences the effect of an infaunal suspension feeding bivalve on estuarine ecosystem function. PLOS ONE 6(10):e27065.

Jones HFE, Pilditch CA, Hamilton DP, Bryan KR. 2017. Impacts of a bivalve mass mortality event on an estuarine food web and bivalve grazing pressure. N Z J Mar Freshw Res 51:37092.

Kang C-K, Lee Y-W, Choy EJ, Shin JK-, Seo I-S, Hong J-S. 2006. Microphytobenthos seasonality determines growth and reproduction in intertidal bivalves. Mar Ecol Prog Ser 315:113-27.

Karlson AML, Nascimento FJA, Näslund J, Elmgren R. 2010. Higher diversity of deposit-feeding macrofauna enhances phytodetritus processing. Ecology 91:1414-23.

Karlson AML, Gorokhova E, Elmgren R. 2014. Nitrogen fixed by cyanobacteria is utilized by deposit-feeders. PLoS ONE 9:e104460.

Karlson AML, Niemand C, Savage C, Pilditch CA. 2016. Density of key-species determines efficiency of macroalgae detritus uptake by intertidal benthic communities. PLoS ONE 11(7):e0158785.

Kaufman MR, Gradinger RR, Bluhm BA, O'Brien DM. 2008. Using stable isotopes to assess carbon and nitrogen turnover in the Arctic sympagic amphipod Onisimus litoralis. Oecologia 158:11-22.

Kelaher BP, Levinton JS. 2003. Variation in detrital enrichment causes spatio-temporal variation in soft-sediment assemblages. Mar Ecol Prog Ser 261:85-97. 
Kelaher BP, Bishop MJ, Potts J, Scanes P, Skilbeck G. 2013. Detrital diversity influences estuarine ecosystem performance. Glob Change Biol 19:1909-18.

Lau DCP, Leung KMY, Dudgeon D. 2012. Preservation effects on $\mathrm{C} / \mathrm{N}$ ratios and stable isotope signatures of freshwater fishes and benthic macroinvertebrates. Limnol Oceanogr Methods 10:75-89.

Layman CA, Arrington DA, Montana CG, Post DM. 2007. Can stable isotope ratios provide for community-wide measures of trophic structure? Ecology 88:42-8.

Leduc D, Probert KP, Frew RD, Hurd CL. 2006. Macroinvertebrate diet in intertidal seagrass and sandflat communities: a study using C, N, and S stable isotopes. N Z J Mar Freshw Res 40:615-29.

Leduc D, Probert PK, Duncan A. 2009. A multi-method approach for identifying meiofaunal trophic connections. Mar Ecol Prog Ser 383:95-111.

Lohrer AM, Halliday NJ, Thrush SF, Hewitt JE, Rodil IF. 2010. Ecosystem functioning in a disturbance-recovery context: contribution of macrofauna to primary production and nutrient release on intertidal sandflats. J Exp Mar Biol Ecol 390:6-13.

Marsden I, Bressington MJ. 2009. Effects of macroalgal mats and hypoxia on burrowing depth of the New Zealand cockle (Austrovenus stutchburyi). Est Coast Shelf Sci 81:438-44.

Murphy AE, Emery KA, Anderson IC, Pace ML, Brush MJ, Rheuban JE. 2016. Quantifying the effects of commercial clam aquaculture on $\mathrm{C}$ and $\mathrm{N}$ cycling: an integrated ecosystem approach. Estuar Coast 39:1746-61.

Newsome SD, Martinez del Rio C, Bearhop S, Phillips DL. 2007. A niche for isotopic ecology. Front Ecol Environ 5:429-36.

Norkko A, Hewitt JE, Thrush SE, Funnel GA. 2001. Benthicpelagic coupling and suspension-feeding bivalves: linking sitespecific sediment flux and biodeposition to benthic community structure. Limnol Oceanogr 46:2067-72.

Norkko A, Villnäs A, Norkko J, Valanako S, Pilditch CA. 2013. Size matters: implications of the loss of large individuals for ecosystem function. Sci Rep 3:2646.

Pratt DR, Lohrer AM, Thrush SF, Hewitt JE, Townsend M, Cartner K, Pilditch CA, Harris RJ, van Colen C, Rodil IF. 2015. Detecting subtle shifts in ecosystem functioning in a dynamic estuarine environment. PLoS ONE 10:e133914.

Rossi F. 2007. Recycle of buried macroalgal detritus in sediments: use of dual-labelling experiments in the field. Mar Biol 150:1073-81.

Rossi F, Gribsholt B, Gazeau F, Di Santo V, Middelburg JJ. 2013. Complex effects of ecosystem engineer loss on benthic ecosystem response to detrital macroalgae. PLoS ONE 8(6):e66650.
Rudnick DT. 1989. Time lags between the deposition and meiobenthic assimilation of phytodetritus. Mar Ecol Prog Ser 50:231-40.

Säwström C, Hyndes GA, Eyre BD, Hugge MD, Fraser MW, Lavery PS, Thomson PG, Tarquinio F, Steinberg PD, Laverock B. 2016. Coastal connectivity and spatial subsidy from a microbial perspective. Ecol Evol 6:6662-71.

Sandwell DR, Pilditch CA, Lohrer AM. 2009. Density dependent effects of an infaunal suspension-feeding bivalve (Austrovenus stutchburyi) on sandflat nutrient fluxes and microphytobenthic productivity. J Exp Mar Biol Ecol 373:16-25.

Snelgrove PVJ, Blackburn TH, Hutchings PA, Alongi DM, Grassle JF, Hummel H, King G, Koike L, Lambshead PJD, Ramsing NB, Solis-Weiss V. 1997. The importance of marine sediment biodiversity in ecosystem processes. Ambio 26:578-83.

Snelgrove PVR, Thrush SF, Wall DH, Norkko A. 2014. Real world biodiversity-ecosystem functioning: a seafloor perspective. Trends Ecol Evol 29:398-405.

Svanbäck R, Bolnick DI. 2007. Intraspecific competition drives increased resource use diversity within a natural population. Proc R Soc B 274:839-44.

Teichberg M, Fox SE, Olsen YS, Valiela I, Martinetto P, Iribarne $\mathrm{O}$ et al. 2010. Eutrophication and macroalgal blooms in temperate and tropical coastal waters: nutrient enrichment experiments with Ulva spp. Glob Change Biol 16:2626-37.

Thrush SF, Hewitt JE, Gibbs M, Lundquist C, Norkko A. 2006. Functional role of large organisms in intertidal communities: community effects and ecosystem function. Ecosystems 9:1029-40

Thrush SF, Hewitt J, Parkes S, Lohrer AM, Pilditch CA, Woodin SA, Wethey DS, Chiantore MC, Asnaghi V, de Juan S, Kraan C, Rodil I, Savage C, van Colen C. 2014. Experimenting with ecosystem interaction networks in search of threshold potentials in real-world marine ecosystems. Ecology 95:14517.

Tyler AC, McGlathery KJ, Anderson IC. 2001. Macroalgae mediation of dissolved organic nitrogen fluxes in a temperate coastal lagoon. Est Coast Shelf Sci 53:155-68.

Wells SR, Wing LC, Smith AM, Smith IWG. 2019. Historical changes in bivalve growth rates indicate ecological consequences of human occupation in estuaries. Aquat Conserv Mar Freshw Ecosyst 29:1-14.

Woodin SA, Volkenborn N, Pilditch CA, Lohrer AM, Wethey DS, Hewitt JE, Thrush SF. 2016. Same pattern, different mechanism: locking onto the role of key species in seafloor ecosystem process. Sci Rep 6:26678.

Yin XW, Wang JJ, Yang M, Xie X. 2019. Evaluation of macroalgal detritus as food source for juvenile Manila clam, Ruditapes philippinarum: effects on growth, amino acid content and fatty acid composition. Aquac Res 50:3579-88. 